\title{
Intraneuronal $\beta$-Amyloid Aggregates, Neurodegeneration, and Neuron Loss in Transgenic Mice with Five Familial Alzheimer's Disease Mutations: Potential Factors in Amyloid Plaque Formation
}

\author{
Holly Oakley, ${ }^{1}$ Sarah L. Cole, ${ }^{1}$ Sreemathi Logan, ${ }^{1}$ Erika Maus, ${ }^{1}$ Pei Shao, ${ }^{1}$ Jeffery Craft, ${ }^{1}$ Angela Guillozet-Bongaarts, \\ Masuo Ohno, ${ }^{2}$ John Disterhoft, ${ }^{2}$ Linda Van Eldik, ${ }^{1}$ Robert Berry, ${ }^{1}$ and Robert Vassar ${ }^{1}$ \\ Departments of ${ }^{1}$ Cell and Molecular Biology and ${ }^{2}$ Physiology, The Feinberg School of Medicine, Northwestern University, Chicago, Illinois 60611
}

\begin{abstract}
Mutations in the genes for amyloid precursor protein (APP) and presenilins (PS1, PS2) increase production of $\beta$-amyloid 42 (A $\beta_{42}$ ) and cause familial Alzheimer's disease (FAD). Transgenic mice that express FAD mutant APP and PS1 overproduce A $\beta_{42}$ and exhibit amyloid plaque pathology similar to that found in $\mathrm{AD}$, but most transgenic models develop plaques slowly. To accelerate plaque development and investigate the effects of very high cerebral $\mathrm{A} \beta_{42}$ levels, we generated APP/PS1 double transgenic mice that coexpress five FAD mutations (5XFAD mice) and additively increase $\mathrm{A} \beta_{42}$ production. 5XFAD mice generate $\mathrm{A} \beta_{42}$ almost exclusively and rapidly accumulate massive cerebral $\mathrm{A} \beta_{42}$ levels. Amyloid deposition (and gliosis) begins at 2 months and reaches a very large burden, especially in subiculum and deep cortical layers. Intraneuronal $\mathrm{A} \beta_{42}$ accumulates in 5XFAD brain starting at 1.5 months of age (before plaques form), is aggregated (as determined by thioflavin S staining), and occurs within neuron soma and neurites. Some amyloid deposits originate within morphologically abnormal neuron soma that contain intraneuronal $\mathrm{A} \beta$. Synaptic markers synaptophysin, syntaxin, and postsynaptic density- 95 decrease with age in 5XFAD brain, and large pyramidal neurons in cortical layer 5 and subiculum are lost. In addition, levels of the activation subunit of cyclin-dependent kinase 5, p25, are elevated significantly at 9 months in 5XFAD brain, although an upward trend is observed by 3 months of age, before significant neurodegeneration or neuron loss. Finally, 5XFAD mice have impaired memory in the Y-maze. Thus, 5XFAD mice rapidly recapitulate major features of $\mathrm{AD}$ amyloid pathology and may be useful models of intraneuronal $\mathrm{A} \beta_{42}$-induced neurodegeneration and amyloid plaque formation.
\end{abstract}

Key words: Alzheimer's disease; transgenic mice; $\mathrm{A} \beta_{42}$; amyloid plaques; intraneuronal $\mathrm{A} \beta$; neuron loss

\section{Introduction}

Amyloid plaques, deposits of the $\beta$-amyloid $(\mathrm{A} \beta)$ peptide (Glenner and Wong, 1984), are defining lesions in Alzheimer's disease (AD) brain. A strong genetic association exists between earlyonset familial forms of $\mathrm{AD}(\mathrm{FAD})$ and the 42 amino acid species of the $\mathrm{A} \beta$ peptide $\left(\mathrm{A} \beta_{42}\right)$ (for review, see Hutton et al., 1998; Younkin, 1998; Sisodia et al., 1999). A $\beta$ is a proteolytic product of the amyloid precursor protein (APP), and autosomal dominant mutations in the genes for APP, presenilin1 (PS1), and presenilin2 (PS2) increase production of $\mathrm{A} \beta_{42}$ and cause FAD. $\mathrm{A} \beta_{42}$ is

\footnotetext{
Received March 20, 2006; revised July 24, 2006; accepted Aug. 24, 2006.

This work was supported by National Institute on Aging Grants P01 AG021184 (Project 1, L.V.E.; Project 4, R.V.; Histology (ore, R.B.) and R01 AG022560 (R.V.) We are indebted to Lynn Doglio and her staff at the Northwestern Transgenic and Targeted Mutagenesis Laboratory for transgene microinjection and production of founder transgenic mice. We also thank the following individuals for their valuable input on this project: Fred Van Leuven for the Thy1 transgene cassette vector, Leong Chew for assistance with confocal imaging, Gopal Thinakaran for the PS1NT antibody, Dennis Selkoe for the R1282 antibody, and Marsel Mesulam, Richard Miller, Gunnar Gouras, Frank Laferla, and Sam Sisodia for thoughtful comments on this manuscript.

Correspondence should be addressed to Dr. Robert Vassar, Department of Cell and Molecular Biology, The Feinberg School of Medicine, Northwestern University, 303 East Chicago Avenue, Chicago, IL 60611. E-mail: r-vassar@northwestern.edu.

D0I:10.1523/JNEUROSCI.1202-06.2006

Copyright $\odot$ 2006 Society for Neuroscience $\quad$ 0270-6474/06/2610129-13\$15.00/0
}

more fibrillogenic than shorter $\mathrm{A} \beta$ peptides, and elevated $\mathrm{A} \beta_{42}$ concentrations are thought to drive the formation of the insoluble fibrils that compose amyloid plaques. The robust association of $\mathrm{A} \beta_{42}$ with FAD argues strongly in favor of a causative role for $\mathrm{A} \beta_{42}$ in the etiology of $\mathrm{AD}$.

$\mathrm{A} \beta$ is cleaved from APP by the sequential action of two proteases, the $\beta$ - and $\gamma$-secretases (for review, see Sisodia et al., 1999; Selkoe, 2001). Initially, the $\beta$-secretase cuts APP at the $\mathrm{N}$ terminus of the $\mathrm{A} \beta$ domain to produce the membrane-bound fragment C99 and the secreted APP ectodomain APPs $\beta$. Subsequently, C99 is cleaved by the $\gamma$-secretase to generate the $\mathrm{C}$ terminus of $\mathrm{A} \beta$. $\gamma$-Secretase cleavage is not precise and produces a series of $A \beta$ peptides of 38-43 amino acids in length. Under normal conditions, a higher proportion of $A \beta$ is produced as the 40 amino acid $\mathrm{A} \beta_{40}$, and less is made as $\mathrm{A} \beta_{42}$. FAD mutations in APP that cluster near the $\beta$ - and $\gamma$-secretase cleavage sites either elevate the production of total $\mathrm{A} \beta$, as is the case with the K670N/ M671L substitution [Swedish mutation (Mullan et al., 1992a)], or increase the generation of $A \beta_{42}$ specifically, as occurs with the I716V [Florida mutation (Eckman et al., 1997)] and V717I [London mutation (Goate et al., 1991)] substitutions. PS1 and PS2 appear to be subunits of the $\gamma$-secretase complex (Esler and 
Wolfe, 2001), and presenilin FAD mutations also elevate $\mathrm{A} \beta_{42}$ generation specifically.

Previous studies have suggested that $\mathrm{A} \beta_{42}$-elevating FAD mutations act in an additive manner to increase $A \beta_{42}$ generation when incorporated within the same molecule. In particular, the intramolecular combination of $1716 \mathrm{~V}$ and V717I mutations within APP doubled $\mathrm{A} \beta_{42}$ production compared with the individual mutations (Eckman et al., 1997), as did the two PS1 FAD mutations M146L and L286V when introduced together into PS1 (Citron et al., 1998). Moreover, the intermolecular combination of $\mathrm{A} \beta_{42}$-elevating mutations in APP and PS1 also additively increased $\mathrm{A} \beta_{42}$ production (Citron et al., 1998).

To additively drive $A \beta_{42}$ generation and create a very rapid $\mathrm{AD}$ amyloid model, we made transgenic mice that coexpress a total of five FAD mutations [APP K670N/M671L (Swedish) + I716V (Florida) + V717I (London) and PS1 M146L+ L286V]. These "5XFAD" transgenic mice develop cerebral amyloid plaques and gliosis at 2 months of age, achieve massive $\mathrm{A} \beta_{42}$ burdens, and have reduced synaptic markers, increased p25 levels, neuron loss, and memory impairment in the Y-maze. Interestingly, we observe accumulation of intraneuronal $\mathrm{A} \beta_{42}$ before plaques form. Intraneuronal $A \beta$ is aggregated, and amyloid plaques appear to originate from neuron cell bodies with intraneuronal $\mathrm{A} \beta$. Accumulation of intraneuronal $\mathrm{A} \beta$ has been observed in the brains of AD (Gouras et al., 2000; Takahashi et al., 2002; Cataldo et al., 2004; Takahashi et al., 2004), Down's syndrome (DS) (Gouras et al., 2000; Gyure et al., 2001; Busciglio et al., 2002; Mori et al., 2002; Cataldo et al., 2004), and AD mouse models (Takahashi et al., 2002; Oddo et al., 2003; Schmitz et al., 2004), implying potential involvement of intraneuronal $A \beta$ in $\mathrm{AD}$ pathology (for review, see Echeverria and Cuello, 2002; Tseng et al., 2004; Gouras et al., 2005). Our results with 5XFAD mice suggest that intraneuronal $A \beta$ aggregates may have a role in neurodegeneration, neuron loss, and amyloid plaque formation.

\section{Materials and Methods}

Generation of transgenic mice. The FAD mutations APP K670N/M671L (770 residue isoform numbering) + I716V + V717I and PS1 M146L + L286V were introduced into APP(695) and PS1 cDNAs by site-directed mutagenesis, then subcloned into exon 2 of the mouse Thy 1 transgene cassette (Moechars et al., 1996), and sequenced following standard procedures. The APP transgene includes the $5^{\prime}$ untranslated region, which contains a putative interleukin-1 $\beta$ (IL- $1 \beta$ ) translational enhancer element (Rogers et al., 1999). After purification of the transgenes from vector sequence, the transgenes were added together in equal proportions and microinjected into the pronuclei of single-cell C57/B6XSJL hybrid embryos by the staff at the Northwestern University Transgenic and Targeted Mutagenesis Laboratory (Hogan et al., 1994; Jankowsky et al., 2001; Oddo et al., 2003). Founder transgenic mice were identified by PCR and confirmed by Southern blot analysis. The three highest APP and PS1 transgene coexpressing lines (Tg6799, Tg7031, and Tg 7092) were bred with B6/SJL F1 hybrids (Taconic Farms, Germantown, NY) for additional analysis.

Immunoblot analysis. Mice were anesthetized with pentobarbital (50 $\mathrm{mg} / \mathrm{kg}$ ) and transcardially perfused with PBS (Invitrogen, Carlsbad, CA) buffer containing protease inhibitor cocktail (Calbiochem, La Jolla, CA). Brains were removed and bisected down the midline; one hemibrain was used for biochemical analysis and the other for histological analysis. For immunoblots and ELISAs, hemibrains were homogenized in four volumes of PBS (Invitrogen) containing protease inhibitor cocktail (Calbiochem). Brain homogenates were then aliquoted into two equal portions, one for immunoblot analysis and the other for ELISA. Two times concentrated radioimmunoprecipitation assay buffer $(100 \mathrm{~mm} \mathrm{NaCl}, 1 \%$ NP-40, $0.25 \%$ sodium deoxycholate, $1 \%$ SDS, $1 \mathrm{~mm}$ EDTA, and $50 \mathrm{~mm}$ Tris $\mathrm{HCl}, \mathrm{pH} 7.4$ ) was added to the homogenate for immunoblotting and briefly sonicated. Protein concentrations were determined using a BCA kit (Pierce, Rockford, IL), and 10-20 $\mu \mathrm{g}$ of protein was run on 10 or $10-14.5 \%$ Tris-HCl SDS-PAGE gels (Bio-Rad, Hercules, CA). After transfer onto polyvinylidene difluoride membrane, blots were incubated in the following primary antibodies: anti-APP (22C11; Chemicon, Temecula, CA), 1:10,000; anti-PS1 N terminal (PS1NT) (gift from Gopal Thinakaran, University of Chicago, Chicago, IL) (Thinakaran et al., 1998), 1:5000; and anti-actin (Sigma, St. Louis, MO), 1:10,000. Peroxidase-conjugated secondary antibodies were applied, and immunoblot signals were detected by enhanced chemiluminescence [Amersham Biosciences (Arlington Heights, IL) or Pierce] and quantified using an Eastman Kodak (Rochester, NY) Image Analyzer.

For neuron marker and neurodegeneration pathway immunoblots, cortex homogenates were prepared in $1 \%$ Triton X-100, PBS, protease inhibitor cocktail (Calbiochem), and Halt Phosphatase Inhibitor Cocktail (Pierce). Protein concentrations were determined using a BCA kit (Pierce), and 5-15 $\mu \mathrm{g}$ of protein was run on $4-12 \%$ Bis-Tris gels (Invitrogen), immunoblotted as above, and incubated with the following antibodies: postsynaptic density-95 (PSD-95) (Chemicon), 1:1000; syntaxin (Chemicon), 1:1000; and p35 (Santa Cruz Biotechnology, Santa Cruz, CA), 1:1000. Detection was performed as described above.

$A \beta_{40}$ and $A \beta_{42}$ ELISAs. For $\mathrm{A} \beta$ ELISAs, PBS/protease inhibitor brain homogenates were supplemented with guanidine $\mathrm{HCl}$ to a final concentration of $5 \mathrm{M}$, sonicated briefly, and serially diluted with ELISA sample buffer. Final guanidine $\mathrm{HCl}$ concentrations were below 0.1 M. Protein concentrations were determined using a BCA kit (Pierce). Sample duplicates were then run on $\mathrm{A} \beta_{40}$ and $\mathrm{A} \beta_{42}$ specific sandwich colorimetric ELISAs following the protocol of the manufacturer (BioSource, Camarillo, CA). Optical densities at $450 \mathrm{~nm}$ of each well were read on a Victor 1420 plate reader (Wallac, Gaithersburg, MD), and sample $A \beta_{40}$ and $\mathrm{A} \beta_{42}$ concentrations were determined by comparison with the $\mathrm{A} \beta_{40}$ and $\mathrm{A} \beta_{42}$ standard curves. All readings were in the linear range of the assay. Finally, sample $\mathrm{A} \beta_{40}$ and $\mathrm{A} \beta_{42}$ concentration values were normalized to total brain protein concentrations and expressed in nanograms of $A \beta$ per milligram total protein. The average of the duplicates was determined, and then the mean and SEM for each age of a given line was calculated.

Synaptophysin ELISA. Synaptophysin levels in whole-brain homogenates were quantified with a capture ELISA as described previously (Schlaf et al., 1998), with the following modifications. The SY38 monoclonal synaptophysin antibody (Chemicon) was used to coat plates at the concentration of $1.75 \mu \mathrm{g} / \mathrm{ml}$, whereas a rabbit polyclonal synaptophysin antibody $(0.35 \mu \mathrm{g} / \mathrm{ml}$; Calbiochem $)$ and an HRP-conjugated goat antirabbit IgG antibody (1:10,000; Jackson ImmunoResearch, West Grove, PA) were used for detection with a tetramethylbenzidine development system (Sigma). Because of the lack of purified synaptophysin, a mouse corticohippocampal homogenate served as a standard, as described previously (Craft et al., 2004).

Histology and immunostaining. After perfusion and dissection, one hemibrain of each mouse was fixed in paraformaldehyde/PBS and cryopreserved in $30 \%$ sucrose/PBS containing $0.01 \%$ sodium azide. Brains were sectioned sagittally on a freezing microtome at $30 \mu \mathrm{m}$. Serial sections were collected in $0.1 \mathrm{~m}$ phosphate buffer, $\mathrm{pH}$ 7.6. Free-floating sections (in most cases adjacent) were then incubated overnight at room temperature with the following primary antibodies: rabbit anti-A $\beta_{42}(1$ : 2500; BioSource), rabbit anti-A $\beta_{40}$ (1:2500; BioSource), biotinylated mouse anti-A $\beta$ (4G8, 1:10,000; Signet Laboratories, Dedham, MA), rabbit anti-A $\beta$ (R1282, 1:500; gift from Dennis Selkoe, Harvard Medical School, Brigham \& Women's Hospital, Boston, MA), rabbit anti-GFAP (G9269, 1:10,000; Sigma), rat anti-F4/80 (MCAP497, 1:10,000; Serotec, Oxford, UK), and anti-neuronal-specific nuclear protein (NeuN) (1:500; Sigma). After washes, the sections were incubated with secondary biotinylated goat anti-rabbit or goat anti-mouse at 1:2000 for $2 \mathrm{~h}$ at room temperature. The Vector Laboratories (Burlingame, CA) ABC kit was used with $\mathrm{DAB}$ as chromogen to visualize the reaction product. The sections were then mounted on charged slides, counterstained with hematoxylin, dehydrated in a series of alcohols, cleared in xylene, and coverslipped. In some cases, after primary antibody incubation, sections were prepared for immunofluorescence microscopy by incubating with FITC- or tetramethylrhodamine isothiocyanate-labeled goat anti-rabbit 
or goat anti-mouse secondary antibodies. Thioflavin $\mathrm{S}$ or thiazin red staining was also used to visualize amyloid. Cresyl violet was used to stain Nissl substance for visualizing neurons for estimating neuronal loss. Light microscopy was performed on a Nikon (Tokyo, Japan) E800 microscope with a Spot Advanced digital camera for capturing images, and confocal images were captured on a LSM510 META system (Zeiss, Oberkochen, Germany).

Spontaneous alternation $Y$-maze task. Spontaneous alternation performance was tested as described previously (Ohno et al., 2004). Each mouse was placed in the center of the symmetrical Y-maze and was allowed to explore freely through the maze during an $8 \mathrm{~min}$ session. The sequence and total number of arms entered was recorded. Experiments were done blind with respect to the genotype of the mice. Percentage alternation is as follows: number of triads containing entries into all three arms/maximum possible alternations (the total number of arms entered -2$) \times 100$.

\section{Results}

\section{Transgenic strategy and generation of 5XFAD mice}

The majority of AD transgenic mouse models take $\sim 6-12$ months, or longer, to form amyloid plaques (for review, see Spires and Hyman, 2005). Because many types of investigations would be facilitated by more rapid plaque development, we endeavored to accelerate amyloid deposition by combining multiple FAD mutations in transgenic mice. Previous studies have shown that mice coexpressing FAD mutant APP and PS1 transgenes exhibit additive increases in $\mathrm{A} \beta_{42}$ production (Borchelt et al., 1996, 1997; Citron et al., 1997; Holcomb et al., 1998), although rarely have more than two $\mathrm{A} \beta_{42}$-elevating FAD mutations been combined in transgenic animals. Intrigued by the reports that intramolecular combination of FAD mutations in either APP or PS1 act additively to increase $\mathrm{A} \beta_{42}$ generation (Eckman et al., 1997; Citron et al., 1998), we established transgenic mouse lines that co-overexpress human APP695 with the Swedish (K670N, M671L), Florida (I716V), and London (V717I) FAD mutations in the same APP molecule and human PS1 harboring two FAD mutations, M146L and L286V (Fig. $1 A$ ). The Swedish mutation increases the production of total $\mathrm{A} \beta$, whereas APP Florida and London, and PS1 M146L and L286V, specifically increase the production of $\mathrm{A} \beta_{42}$ (for review, see Sisodia et al., 1999; Selkoe, 2001). From the previous studies, it seemed likely that coexpression of these $\mathrm{A} \beta_{42}$-elevating mutations, in both intermolecular and intramolecular combination, would increase $\mathrm{A} \beta_{42}$ generation in an additive manner in transgenic mice. Because $\mathrm{A} \beta_{42}$ is thought to drive amyloid plaque formation and $\mathrm{AD}$ pathogenesis, we reasoned that these transgenics might exhibit more rapid amyloid deposition than previous models and allow us to investigate the overall effects of very high $\mathrm{A} \beta_{42}$ levels in the brain.

Transgenic lines were produced by pronuclear coinjection of APP and PS1 transgenes, each using the neuron-specific mouse Thyl promoter to drive overexpression in the brain (Moechars et al., 1996). Previous work has demonstrated that coinjection results in efficient transgene cointegration, often together at the same genomic locus, thus enabling stable germ-line transmission and transgene coinheritance (Jankowsky et al., 2001; Oddo et al., 2003). Of 17 total founders, four were positive for the APP transgene only, two were positive for the PS1 transgene only, and 11 were positive for both APP and PS1 transgenes (data not shown). Transgenic offspring of most of the bigenic founders were double positive for APP and PS1 transgenes, indicating stable genomic cointegration and germ-line transmission of both transgenes. Because the bigenics carry five FAD mutations, we collectively refer to them as $5 \mathrm{XFAD}$ mice.

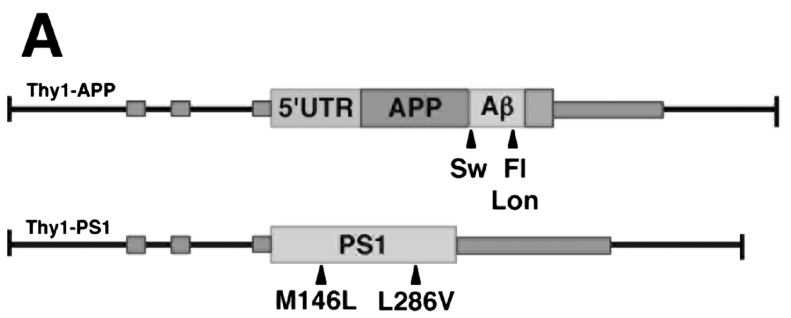

B

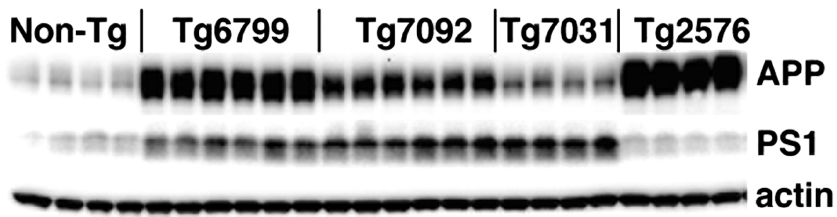

Figure 1. 5XFAD transgenes and expression levels. $\boldsymbol{A}$, Schematic diagram of 5XFAD APP and PS1 transgenes. FAD mutations in Thy1-APP and Thy1-PS1 transgenes are indicated by arrowheads. Sw, Swedish mutation; Lon, London mutation; Fl, FL mutation. Small gray rectangles represent Thy1 exons. Coding regions of APP and PS1 are represented by larger rectangles and are shown inserted into Thy1 exon 2 of the mouse Thy1 transgene expression cassette (Moechars et al., 1996). The APP transgene has the $5^{\prime}$ untranslated region (5'UTR) of APP containing an IL-1 $\beta$ responsive translational element (Rogers et al., 1999). $\boldsymbol{B}$, Immunoblot analysis of 5XFAD lines showing expression levels of transgene-derived APP and PS1. Whole-brain homogenate $(15 \mu \mathrm{g})$ from 6-month-old 5XFAD lines (Tg6799, $\mathrm{Tg} 7092$, and $\mathrm{Tg} 7031), \mathrm{Tg} 2576$, and nontransgenic controls were run on SDS-PAGE and immunoblotted, followed by detection with APP (22C11; top row) and PS1 (PS1NT; middle row) antibodies. Blots were stripped and incubated with actin antibody (bottom row) as a loading control. A representative selection of male and female mice for each line is shown. Note that 5XFAD lines express less APP than Tg2576, yet all develop amyloid deposits much earlier than Tg2576 (see Figs. 3, 4).

To determine the levels of APP and PS1 transgene expression, hemizygous transgenic offspring of the 5XFAD founders were killed, and brain homogenates were prepared for immunoblot analysis with anti-APP (22C11) and anti-PS1NT (Thinakaran et al., 1998) antibodies (Fig. 1 B). After initial analyses, we chose for additional study three APP and PS1 coexpressing 5XFAD lines that overexpress APP at high (Tg6799), medium (Tg7092), and low (Tg7031) levels. The well established Tg2576 mouse model of $\mathrm{AD}$, which overexpresses APP with the Swedish mutation (Hsiao et al., 1996), was used as a control in these studies and makes slightly more APP than our highest expressing line, Tg6799. The three 5XFAD lines have been maintained as hemizygotes on a B6/SJL hybrid background for more than 10 generations and show stable germ-line transmission and expression of both APP and PS1 transgenes, demonstrating that the 5XFAD mice breed as single transgenics.

5XFAD mice rapidly accumulate massive $\mathrm{A} \boldsymbol{\beta}_{42}$ levels in brain To determine whether 5XFAD mice exhibited additively increased $\mathrm{A} \beta_{42}$ production, we measured cerebral levels of $\mathrm{A} \beta_{40}$ and $A \beta_{42}$ in whole-brain homogenates using specific sandwich ELISAs. As predicted, the three 5XFAD transgenic lines had dramatically higher levels of $\mathrm{A} \beta_{42}$ than those of $\mathrm{A} \beta_{40}$ (Fig. 2). $\mathrm{A} \beta_{42}$ levels increased in a nearly linear manner as 5XFAD mice aged. The $\mathrm{A} \beta_{42}$ load and the rate of the $\mathrm{A} \beta_{42}$ increase were proportional to the level of APP transgene expression for a given line. For example, Tg6799 had the highest APP expression level, the greatest $\mathrm{A} \beta_{42}$ burden $(\sim 140 \mathrm{ng} / \mathrm{mg}$ total brain protein $)$, and the fastest rate of $\mathrm{A} \beta_{42}$ accumulation (Fig. $2 A$ ). In contrast, Tg7031 had the 


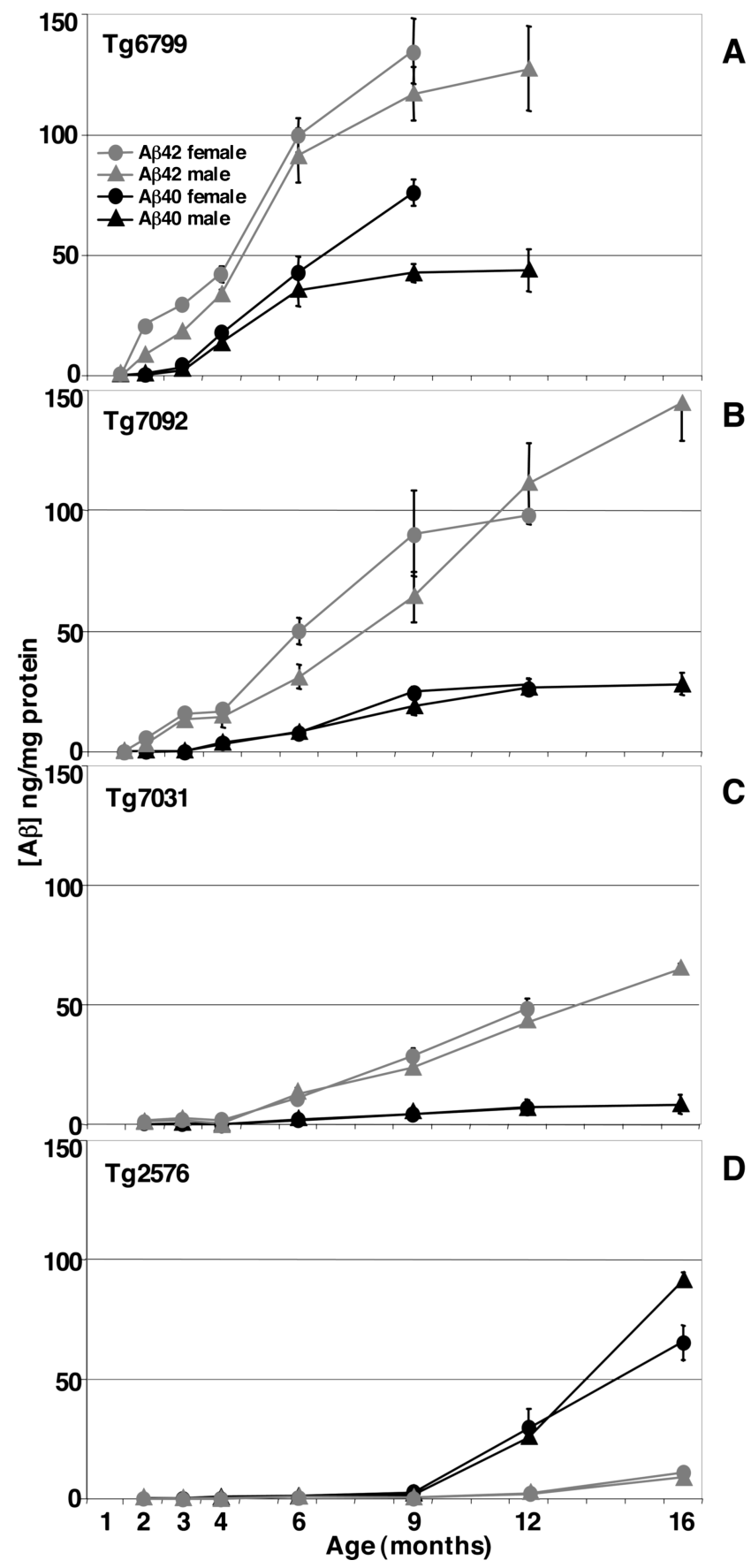

Figure 2. Rapid increase of cerebral $A \beta_{42}$ levels in $5 X F A D$ lines. Whole-brain homogenates from 1.5- to 16-month-old 5XFAD mice ( $\boldsymbol{A}, \operatorname{Tg} 6799 ; \boldsymbol{B}, \mathrm{Tg} 7092 ; \boldsymbol{C}, \operatorname{Tg} 7031)$ and $\operatorname{Tg} 2576$ (D) were prepared in $5 \mathrm{~m}$ guanidine $\mathrm{HCl}$ to solubilize amyloid plaques, and $1 \mathrm{mg}$ of total protein was analyzed by $A \beta_{40}$ (black) and $A \beta_{42}$ (gray) end-specific sandwich ELISAs. A $\beta$ concentrations are expressed in nanograms per milligram of total brain protein. The means of male (triangles) and female (circles) samples are plotted separately. Four to five mice of each genotype per gender and age were analyzed. Error bars represent SEM. At young ages, 5 XFAD mice generated A $\beta_{42}$ almost exclusively. $A \beta_{40}$ levels began to rise at older ages but were always much lower than $A \beta_{42}$ levels. In contrast, for a given age, $\operatorname{Tg} 2576$ had very little $A \beta_{42}$ compared with that of the 5XFAD lines, and $A \beta_{40}$ levels were much greater than $A \beta_{42}$ levels for Tg2576 at all ages. Note that the $A \beta_{42}$ levels of the three 5 XFAD lines are directly proportional to APP transgene expression levels (see Fig. 1B).

lowest levels of both APP and $\mathrm{A} \beta_{42}(\sim 60 \mathrm{ng} / \mathrm{mg}$ total brain protein) and had the slowest rate of $A \beta_{42}$ increase (Fig. $2 C$ ).

Cerebral $\mathrm{A} \beta_{42}$ levels began rising at very young ages in $5 \mathrm{XFAD}$ mice: 1.5, 2, and 4 months for Tg6799, Tg7092, and Tg7031, respectively (Fig. 2). For example, in the highest expressing line, Tg6799, at 1.5 months (the earliest age we tested), brain $\mathrm{A} \beta_{42}$ levels were $\sim 0.3-0.7 \mathrm{ng} / \mathrm{mg}$ protein (background is $\sim 0.1 \mathrm{ng}$ / $\mathrm{mg}$ ), but, by 2 months, $\mathrm{A} \beta_{42}$ levels rose to $\sim 9-21 \mathrm{ng} / \mathrm{mg}$ protein, a very steep increase in just $\sim 2$ weeks. Interestingly, young 5XFAD mice produced $\mathrm{A} \beta_{42}$ almost exclusively. With age, $\mathrm{A} \beta_{40}$ levels also began to rise in transgenic brains, but the $\mathrm{A} \beta_{40}$ increase typically lagged $\sim 2-3$ months behind the $\mathrm{A} \beta_{42}$ increase for a given line. In addition, the rate of the $A \beta_{40}$ increase was less than that of $\mathrm{A} \beta_{42}$ for all lines. The $\mathrm{A} \beta_{42} / \mathrm{A} \beta_{40}$ ratios were very high in young mice, averaging $\sim 25$, but decreased to $\sim 5$ as a result of the increasing $\mathrm{A} \beta_{40}$ levels with age.

Levels of $\mathrm{A} \beta_{42}$ in the 5XFAD lines far exceeded those in Tg2576, which had $\sim 0.1-0.5 \mathrm{ng} \mathrm{A} \beta_{42} / \mathrm{mg}$ total brain protein up to 9 months, $\sim 2 \mathrm{ng} \mathrm{A} \beta_{42} / \mathrm{mg}$ total brain protein at 12 months, and $\sim 10 \mathrm{ng} \mathrm{A} \beta_{42} / \mathrm{mg}$ total brain protein at 16 months (Fig. $2 \mathrm{D}$ ). Moreover, the $\mathrm{A} \beta_{42} / \mathrm{A} \beta_{40}$ ratio of $\mathrm{Tg} 2576$ was much lower than that of the 5XFAD lines, reaching a maximum of $\sim 0.1-0.2$ at 9-16 months. Finally, we noted that young female Tg6799 and Tg7092 mice tended to have slightly higher $\mathrm{A} \beta_{42}$ levels than agematched males, but this trend appeared to diminish at older ages. Together, our data demonstrate that 5XFAD mice accumulate massive amounts of cerebral $\mathrm{A} \beta_{42}$ at young ages and generate much more $\mathrm{A} \beta_{42}$ than $\mathrm{A} \beta_{40}$, suggesting cumulative effects of the five FAD mutations on $\mathrm{A} \beta_{42}$ production.

5XFAD mice display very early amyloid deposition and gliosis Given the very high levels of $\mathrm{A} \beta_{42}$ that rapidly accumulated in 5 XFAD brains, we anticipated that 5XFAD mice would show abundant amyloid deposition at young ages. Indeed, 5XFAD brain sections processed for histological detection of amyloid exhibited robust plaque deposition that was proportional to cerebral $\mathrm{A} \beta_{42}$ levels for a given line. Deposits were immunoreactive with 4G8 (anti-A $\beta$ total) (Fig. $3 A-C$ ), anti-A $\beta_{42}$, and anti-A $\beta_{40}$ end-specific antibodies (Fig. $4 A-H$ ) and were positive after staining with thioflavin S (Fig. $3 E, F$ ) and thiazin red (Fig. $3 G$ ), demonstrating that the deposits are composed of aggregated $\beta$-pleated sheet amyloid.

Tg6799, the line with the highest $\mathrm{A} \beta_{42}$ levels, showed the earliest amyloid deposition by anti- $\mathrm{A} \beta_{42}$ immunohistochemistry and thioflavin S staining, starting at 2 months (Figs. 3E, $4 A$ ) and following closely the initial rise in $\mathrm{A} \beta_{42}$ level by ELISA observed at 1.5 months (Fig. 2A). Deposition in Tg7092 and Tg7031 was delayed relative to that in Tg6799, beginning at 4 months (data not shown) and 6 months (Fig. $3 B$ ), respectively, reflecting the correspondingly lower $\mathrm{A} \beta_{42}$ levels for these lines. In contrast, Tg2576 mice did not begin to deposit amyloid until $\sim 9-12$ months of age (data not shown) (Hsiao et al., 1996). As expected, the rate of deposition and the total amyloid burden in 5XFAD mice were directly proportional to cerebral $\mathrm{A} \beta_{42}$ levels for a given line; amyloid deposition increased rapidly in Tg6799 with age, reaching massive levels by 6 months (Fig. $4 C$ ), whereas the plaque loads in $\mathrm{Tg} 7092$ and Tg7031 increased more slowly and were quantitatively less than that of Tg6799 (data not shown). We also performed anti-A $\beta_{40}$ immunohistochemistry on Tg6799 brain sections and observed substantially weaker $\mathrm{A} \beta_{40}$ immunoreactivity than that of $\mathrm{A} \beta_{42}$ in amyloid deposits (Fig. $4 E-H$ ), thus paralleling the lower $\mathrm{A} \beta_{40}$ levels as measured by ELISA (Fig. $2 A$ ).

All three 5XFAD lines had qualitatively similar spatial patterns of amyloid deposition in the brain. In young mice, plaques first appeared in deep layers of the cortex and in the subiculum (Fig. $4 A, B)$. As mice aged, amyloid deposits spread to fill much of the cortex, subiculum, and hippocampus (Fig. $4 C, D$ ). Plaques were 

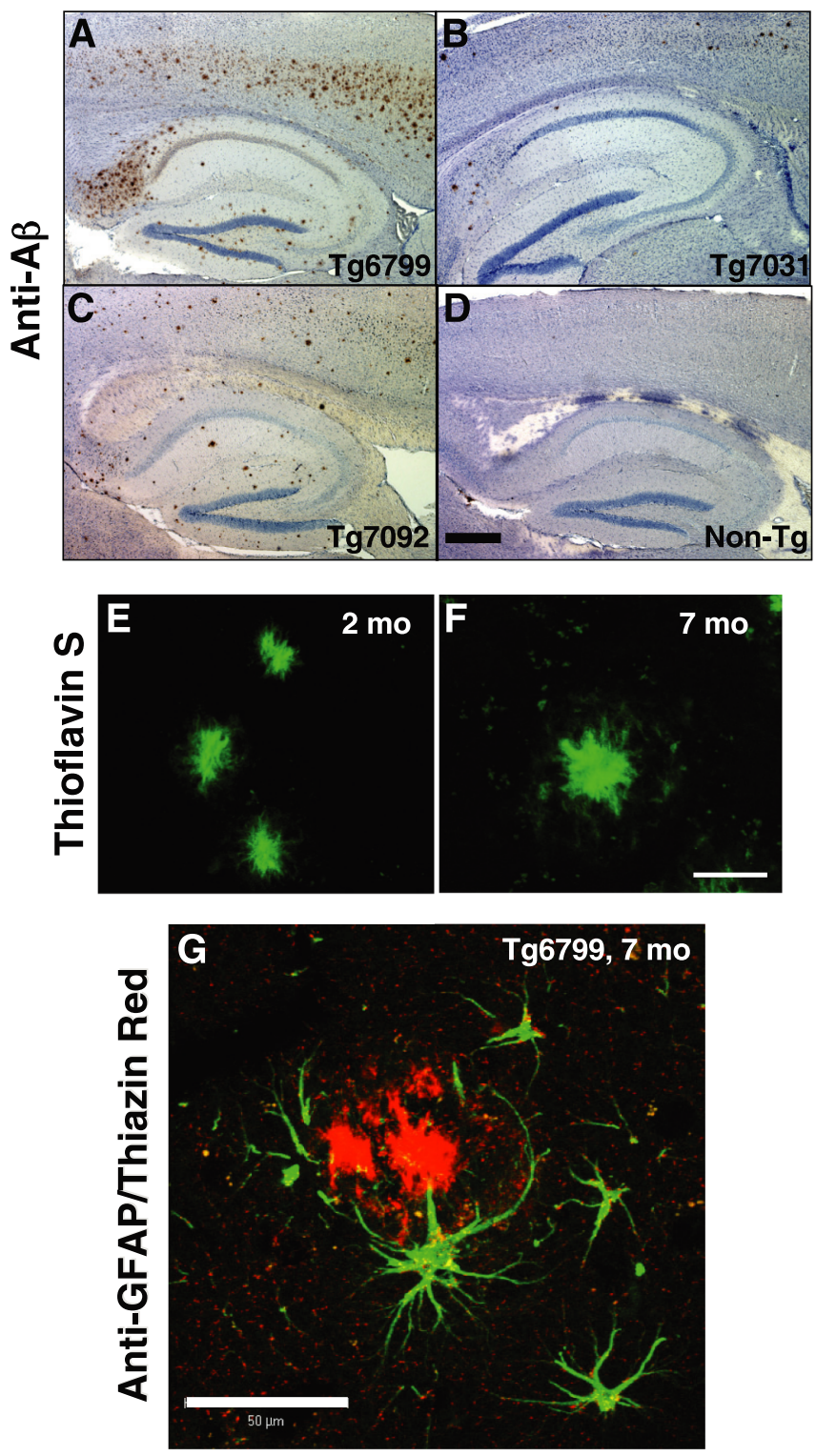

Figure 3. Amyloid deposition and gliosis in 5XFAD lines. Parasagittal serial sections of brains from Tg6799 (A, E-G), Tg7031 (B), Tg7092 (C), and nontransgenic control (D) mice were stained with anti-A $\beta(4 G 8 ; \boldsymbol{A}-\boldsymbol{D})$, thioflavin $\boldsymbol{S}(\boldsymbol{E}, \boldsymbol{F})$, or anti-GFAP and thiazin red $(\boldsymbol{G})$ and imaged by bright-field $(\boldsymbol{A}-\boldsymbol{D})$ or confocal $(\boldsymbol{E}-\boldsymbol{G})$ microscopy. Ages of mice were $2(\boldsymbol{E}), 6(\boldsymbol{A}-\boldsymbol{D})$, and $7(\boldsymbol{F}, \boldsymbol{G})$ months. $\boldsymbol{A}-\boldsymbol{D}$, Shown are sections including the hippocampus and cortex of representative 6-month-old 5XFAD mice from each line stained with anti-A $\beta$ (brown) and hematoxylin (blue). Across the 5XFAD lines, the relative amounts of amyloid burden (and gliosis; data not shown) correlated with $A \beta_{42}$ levels as measured by ELISA (Fig. 2). Scale bar (in D): $\boldsymbol{A}-\boldsymbol{D}, 1 \mathrm{~mm}$. $\boldsymbol{E}, \boldsymbol{F}$, Brain sections of representative 2-month-old $(\boldsymbol{E})$ and 7-month-old $(\boldsymbol{F})$ Tg6799 mice were stained with thioflavin $S$ (green). Amyloid deposits labeled strongly with thioflavin $S$, indicating that $\mathrm{A} \beta$ was in an aggregated $\beta$-pleated sheet conformation. Note that plaque sizes $(\sim 20$ $\mu \mathrm{m}$ ) are similar to those of large neuron cell bodies (data not shown). Scale bar (in $\boldsymbol{F}$ ): $\boldsymbol{E}, \boldsymbol{F}, 20$ $\mu \mathrm{m} . \boldsymbol{G}$, Activated astrocytes around a Tg6799 plaque. Brain section of a representative 7-month-old Tg6799 mouse costained with thiazin red (to label $\beta$-pleated sheet amyloid) and anti-GFAP antibody (green). The astrocytes adjacent to the amyloid plaque display ramified processes and express GFAP, indicative of an activated phenotype associated with inflammation. Scale bar, $50 \mu \mathrm{m}$.

also observed in thalamus, brainstem, and olfactory bulb in older mice, but deposits were less numerous in these brain regions (data not shown). Amyloid deposition did not appear in the cerebellum of 5XFAD mice (data not shown). As expected, the spatial pattern of plaques in $5 \mathrm{XFAD}$ mice agreed well with those of previously reported Thyl promoter-driven APP transgenic mice (Sturchler-Pierrat et al., 1997; Moechars et al., 1999; Oddo et al., 2003). Interestingly, amyloid deposits in 5XFAD mice were typically smaller $(\sim 20 \mu \mathrm{m})$ but vastly more numerous than those observed in Tg2576 (data not shown), possibly because elevated $\mathrm{A} \beta_{42}$ levels may have resulted in greater plaque seed density in the $5 X F A D$ lines. Together, our results demonstrate that the very high cerebral $\mathrm{A} \beta_{42}$ levels caused by the five FAD mutations drive the early formation of amyloid deposits that rapidly increase to large numbers, most notably in 5XFAD line Tg6799.

Neuroinflammation is a hallmark of AD brain and is characterized by the presence of activated astrocytes and microglia surrounding amyloid plaques (for review, see Akiyama et al., 2000). Similar to AD, APP transgenic mouse models have elevated inflammation markers and gliosis associated with amyloid deposits (Games et al., 1995; Hsiao et al., 1996; Sturchler-Pierrat et al., 1997). The 5XFAD lines also exhibited neuroinflammation, as demonstrated by astrogliosis and microgliosis (Figs. 3G, 4I-P). Immunostaining for glial activation markers GFAP (astrocytes) and F4/80 (microglia) revealed that gliosis was proportional to $\mathrm{A} \beta_{42}$ levels and amyloid deposition in 5XFAD brains and began at approximately the time when plaques initially appeared in each line. Tg6799 had GFAP-positive astrocytes and F4/80-positive microglia beginning at 2 months of age (Fig. $4 I, M$ ), whereas the appearance of activated glia in Tg7092 and Tg7031 started at 4 and 6 months, respectively (data not shown). The number of activated astrocytes and microglia increased with age for each line, paralleling the age-related rise in amyloid burden. By 9 months, Tg6799 had robust gliosis in cortex and hippocampus (Fig. $4 L, P$ ), whereas gliosis in Tg2576 did not become significant until after 9 months of age (data not shown). The spatial pattern of gliosis in 5XFAD brain closely followed the distribution of amyloid deposits (Fig. 4I-P). Similar to AD, GFAPimmunoreactive astrocytes were often observed surrounding amyloid deposits in 5XFAD brain (Fig. 3G). As a whole, our data indicate that 5XFAD mice display characteristics of neuroinflammation that appear similar to those observed in $\mathrm{AD}$ brain.

In addition to amyloid plaques, neurofibrillary tangles composed of hyperphosphorylated tau are characteristic lesions found in AD brain (Lee et al., 1991). To determine whether our 5XFAD mice exhibited abnormal tau phosphorylation similar to that observed in neurofibrillary tangles, we immunostained sections of Tg6799 brain from aged mice with antibody AT8 (Biernat et al., 1992). We did not observe significant staining of 5XFAD brain sections with this abnormal tau phosphorylation antibody (data not shown), but the presence of other phospho-tau epitopes has not yet been investigated. Similar to other APP single and APP/PS1 double-transgenic mice, we did not notice any neurofibrillary tangles in 5XFAD brain.

\section{XFAD mice have robust intraneuronal $A \beta$ labeling}

Recent studies have reported intraneuronal $\mathrm{A} \beta$ in $\mathrm{AD}$, Down's syndrome, and APP transgenic brains (for review, see Echeverria and Cuello, 2002; Tseng et al., 2004; Gouras et al., 2005), suggesting that intraneuronal $\mathrm{A} \beta$ may play a role in $\mathrm{AD}$ pathology. In some cases, plaques in $\mathrm{AD}$ brain have appeared to originate from neuron cell bodies that contained intraneuronal $\mathrm{A} \beta$ (Gouras et al., 2000; D'Andrea et al., 2001). Interestingly, we also observed intraneuronal $\mathrm{A} \beta$ in the brains of 5XFAD mice, especially in the highest expressing line, Tg6799. Immunostaining of Tg6799 brain sections with anti-A $\beta_{42} \mathrm{C}$ terminus, $4 \mathrm{G} 8$, and R1282 (antiA $\beta$ total) (Joachim et al., 1991) antibodies revealed strong subcellular labeling primarily within large pyramidal neurons of corti- 
cal layer 5 and the subiculum (Fig. 5A$C, G$ ) (supplemental data, available at www.jneurosci.org as supplemental material). Anti-A $\beta_{42}$ end-specific immunoreactivity was predominantly punctate, suggesting that $\mathrm{A} \beta_{42}$ accumulation occurred within vesicular compartments (Fig. 5A,C). The anti- $\mathrm{A} \beta_{42} \mathrm{C}$ terminus antibody does not recognize full-length APP or APP C-terminal fragments (CTFs); therefore, the staining pattern accurately reflects $\mathrm{A} \beta_{42}$ intraneuronal localization. The intraneuronal $\mathrm{A} \beta$ immunostaining first appeared at 1.5 months of age in Tg6799 (Fig. $5 A$, inset), coinciding with the initial rise in cerebral $\mathrm{A} \beta_{42}$ levels and occurring immediately before the formation of amyloid deposits at 2 months in this line. Staining with 4G8 (Fig. 5B) and R1282 (Fig. 5G) (supplemental data, available at www.jneurosci.org as supplemental material) antibodies also showed punctate intraneuronal labeling, as well as diffuse lowerintensity staining in some neurons. In addition to total $A \beta, 4 G 8$ and R1282 also recognize full-length APP and APP CTFs, which may be responsible for this diffuse immunostaining. It is noteworthy that large 4G8-labeled intraneuronal accumulations were observed near the region of the axon hillock (Fig. 5B, black arrows).

The observation of intense intraneuronal $\mathrm{A} \beta_{42}$ immunostaining in Tg6799 suggested that $A \beta_{42}$ concentrations within intracellular puncta may have been high and implied the possibility that intraneuronal $\mathrm{A} \beta_{42}$ could have been aggregated. To investigate this hypothesis, we examined thioflavin S-stained Tg6799 brain sections for labeled intraneuronal puncta. Indeed, thioflavin $S$ staining revealed a punctate, subcellular pattern within cell bodies of large pyramidal neurons of Tg6799 brain (Fig. $5 D, E$ ), demonstrating that intraneuronal $\mathrm{A} \beta_{42}$ had formed $\beta$-pleated sheet aggregates. These thioflavin S-positive puncta were of similar number and spatial pattern as the intraneuronal $A \beta_{42}$ immunostained puncta and were not observed in negative control mice (data not shown). The approximate 1:1 ratio of thioflavin S-positive and $\mathrm{A} \beta_{42}$-positive puncta suggested that much of the intraneuronal $A \beta_{42}$ was in an aggregated state. In addition to puncta within neuron cell bodies, thioflavin S-positive linear structures appearing to be neurites were observed in Tg6799 cortex (Fig. 5F). Together, these observations suggest that intraneuronal $\mathrm{A} \beta_{42}$ concentrations are high enough in intracellular compartments to form aggregates within the cell bodies and neurites of large pyramidal neurons in Tg6799 mice.

The presence of thioflavin S-positive intracellular $\mathrm{A} \beta_{42}$ aggregates within $\operatorname{Tg} 6799$ neurons suggested the possibility of an "inside-out" process in which intraneuronal $\mathrm{A} \beta_{42}$ aggregates lead to neurodegeneration and amyloid plaque formation. If so, we reasoned that we might observe neurons at a stage of degeneration with plaques appearing to originate from cell bodies. Indeed, Tg6799 brain sections stained with anti-A $\beta$ antibody occasionally showed intraneuronal $\mathrm{A} \beta$-containing soma in close physical association with amyloid deposits (Fig. $5 G$, arrowhead) (supplemental plaque seed movie, available at www.jneurosci.org as supplemental material). These neurons stained weakly with antibod- ies that recognize the neuronal marker NeuN and had abnormal morphologies, suggesting that the neurons were in the process of degeneration. Plaque-associated neurons were relatively rare within Tg6799 brain sections, implying that only a few neurons had made the transition to this stage at the time of fixation.

In support of the hypothesis that some plaques may form from intraneuronal $\mathrm{A} \beta$ aggregates within degenerating neurons, we observed that the highest density of amyloid deposits occurred in deep cortical layers and subiculum, the same regions that had the greatest number of intraneuronal $\mathrm{A} \beta$-containing neurons in Tg6799 brain. Some neurites were also labeled with anti-A $\beta$ antibody (Fig. $5 G$, arrows). As a whole, our results show that (1) 5XFAD mice accumulate intraneuronal $A \beta$ before the start of amyloid deposition, (2) intraneuronal $\mathrm{A} \beta$ aggregates occur mainly in large pyramidal neurons of deep cortical layers and subiculum, and (3) some amyloid plaques appear to originate from intracellular $\mathrm{A} \beta$-containing neurons that have abnormal, degenerated morphologies.

\section{XFAD mice exhibit neurodegeneration and neuron loss}

Given our observations that some 5XFAD neurons contained intraneuronal $\mathrm{A} \beta$ aggregates, displayed disrupted-appearing morphologies, and were in close physical contact with amyloid deposits, we hypothesized that intraneuronal $\mathrm{A} \beta$ might be associated with neurodegeneration and neuron loss in SXFAD brain. To initially investigate this possibility, we measured synaptophysin levels in whole-brain homogenates of Tg6799 mice by ELISA, which has greater accuracy and precision than immunoblot analysis. We observed that whole-brain synaptophysin levels decreased in Tg6799 brains beginning at 4 months of age and that, by 9 months, synaptophysin levels were $\sim 75 \%$ of those in agematched nontransgenic controls (Fig. $6 \mathrm{~A}$ ), demonstrating signif- 


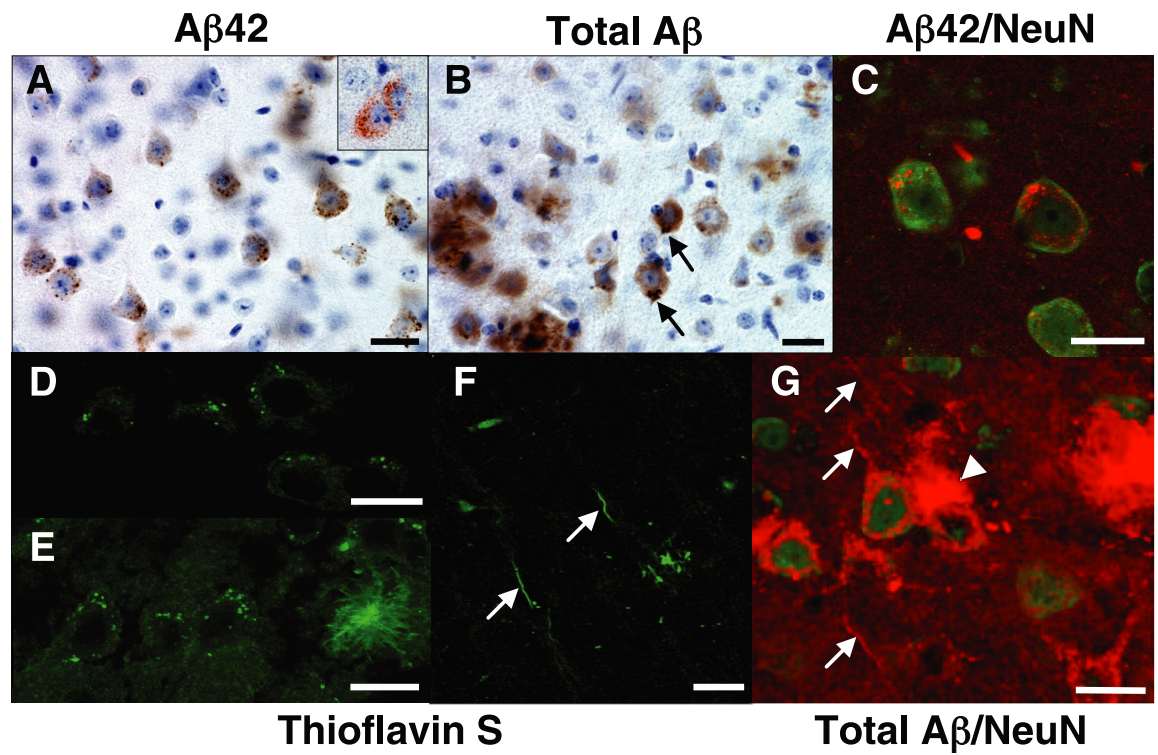

Figure 5. Intraneuronal $A \beta$ accumulation in Tg6799: intracellular $A \beta$ aggregates and plaque formation. Brain sections from representative 1.5- to 6-month-old Tg6799 mice were processed for immunocytochemistry with anti-A $\beta$ antibodies $(\boldsymbol{A}-\boldsymbol{C}, \mathbf{G})$ or stained with thioflavin $\boldsymbol{S}(\boldsymbol{D}-\boldsymbol{F})$. Some sections were counterstained with hematoxylin $(\boldsymbol{A}, \boldsymbol{B})$ or with an antibody that recognizes the neuronal marker NeuN (green stain in $\boldsymbol{C}, \boldsymbol{G})$. Anti-A $\beta$ antibodies used were specific for the $C$ terminus of $A \beta_{42}(\boldsymbol{A}$, brown; $\boldsymbol{C}$, red) or recognized all forms of $A \beta(\boldsymbol{B}, 4 \mathrm{G} 8$, brown; $\boldsymbol{G}, \mathrm{R} 1282$, red). Tg6799 ages were 1.5 ( $\boldsymbol{A}$, inset), $2(\boldsymbol{A}, \boldsymbol{C}, \boldsymbol{D}, \boldsymbol{F}, \boldsymbol{G}), 3(\boldsymbol{E})$, and 6 (B) months. Intraneuronal $A \beta$ accumulations were primarily observed as small puncta, although occasional large irregular accumulations were seen near the axon hillock (black arrows; $\boldsymbol{B}$ ). Importantly, thioflavin $S$ staining revealed intraneuronal $A \beta$ aggregates consisting of $\beta$-pleated sheet amyloid accumulations within soma (punctate signals; $\boldsymbol{D}, \boldsymbol{E}$ ) and neurites (linear structures, white arrows; $\boldsymbol{F}$ ). Note the thioflavin S-positive amyloid plaque (right; $\boldsymbol{E}$ ). In some sections $(\boldsymbol{G})$, an amyloid deposit (white arrowhead) was observed to originate from a neuron cell body with abnormal, disrupted-appearing morphology. This neuron had very little anti-NeuN antibody staining (green), indicating that it was likely in the process of degeneration. In addition, other neurons in the section appeared to be in various stages of degeneration (e.g., bottom right; $\boldsymbol{G}$ ) and were also in close proximity to amyloid plaques (e.g., far left center; $\boldsymbol{G}$ ). Note the presence of $A \beta$-filled neurites passing through the section (red linear structures, white arrows; $\mathbf{G}$ ). Interestingly, plaque sizes were typically of the same magnitude as neuronal soma. Additional amyloid plaques can be seen at the bottom left in $\boldsymbol{B}$ and at the top right in $\mathbf{G}$. For a movie of a three-dimensional reconstruction of the Z-stack sections in $\mathbf{G}$, see supplemental material (available at www.jneurosci.org). Scale bars, $20 \mu \mathrm{m}$.

icant degeneration of synapses in 5XFAD mice. To confirm these results, we performed immunoblot analysis of homogenates from cortexes of 3-, 9-, and 12-month-old Tg6799 mice with antibodies against syntaxin and PSD-95 (Fig. 6B,C) and found that the levels of these synaptic markers were also reduced at 9 and 12 months of age compared with control. Together, these results demonstrate synaptic degeneration in Tg6799 brain.

Because of the spatial pattern of intraneuronal $\mathrm{A} \beta$, we suspected that degeneration in Tg6799 may be restricted to specific neuronal populations. We reasoned that we might observe loss of certain neuron subpopulations in Tg6799 brain and that loss would most likely occur in the intracellular $\mathrm{A} \beta$-containing neuron populations. To test this, we stained brain sections of 9-month-old Tg6799 and nontransgenic controls with cresyl violet and examined them for evidence of neuron loss. As predicted, we found that large pyramidal neurons in cortical layer 5 were visibly reduced in number in Tg6799 compared with control (Fig. $7 A-D$ ). Moreover, cortical layer 1 was significantly thinner in Tg6799 relative to control (Fig. 7A,B), most likely attributable to the loss of layer 5 neuron dendrites that project to and ramify in layer 1 . In addition, neurons in Tg6799 subiculum appeared very pale or were missing entirely (Fig. $7 F$ ). Neurons in other cortical layers, hippocampus, and elsewhere in the brain appeared relatively intact by visual inspection, although we did not perform neuron counting and it is possible that additional neuron populations were also affected.

It is important to note that the neuron loss in cortical layer 5 and subiculum occurred in the brain regions with the highest levels of both intraneuronal $\mathrm{A} \beta$ accumulation and amyloid plaque burden (Fig. 4D). We also observed that glial cells, identified by small nuclei that stained darkly with cresyl violet, were present in much larger numbers throughout the plaque-bearing regions of Tg6799 brain (Fig. $7 F$ ) compared with nonplaque regions and control. Neurons were easily distinguished from glial cells based on the larger neuron cell body and the prominent nuclear nucleolus. Together, our results indicate that 5XFAD mice exhibit significant neurodegeneration and loss of large pyramidal neurons, which appear to correlate with intraneuronal $\mathrm{A} \beta$ and amyloid plaques, respectively.

To gain insight into the molecular mechanism of synaptic degeneration and neuron loss in Tg6799, we performed immunoblot analysis of cortex homogenates from 3-, 9-, and 12-month-old mice using an antibody against the neurodegeneration pathway marker $\mathrm{p} 25$. We found that levels of p25 were increased to $\sim 150 \%$ of control in Tg6799 cortex at 9 and 12 months, with an upward trend at 3 months when intraneuronal $\mathrm{A} \beta$ aggregates were present (Fig. $8 A, B$ ). Thus, elevated p 25 correlates with synaptic degeneration and neuron loss in 5XFAD brain and may be associated with intraneuronal $A \beta$ aggregates.

\section{XFAD mice develop spatial memory deficits}

$\mathrm{AD}$ is an amnestic disorder, and it has been shown that high cerebral $A \beta$ levels correlate with memory impairments in APP transgenic mice (for review, see Ashe, 2001). To determine whether our 5XFAD mice also develop behavioral deficits, we tested 2-month-old and 4- to 5-month-old Tg6799 mice for spontaneous alternation performance in the Y-maze (Ohno et al., 2004). This learning task does not involve any training, reward, or punishment and allowed us to assess hippocampus-dependent spatial working memory in Tg6799. At 2 months of age, spontaneous alternation in the Y-maze for Tg6799 was similar to that for age-matched nontransgenic littermates. However, by $4-5$ months of age, Tg6799 mice were significantly impaired in this task compared with nontransgenic control mice (Fig. 9A). The number of arms entered during the test was comparable for Tg6799 and control mice at both ages, indicating that Tg6799 had normal motor function and exploratory activity (Fig. 9B). Tg6799 mice have also been tested in trace and contextual fear conditioning paradigms and the Morris water maze, and they also exhibited deficits in these other hippocampus-dependent memory tasks (Ohno et al., 2006). These results demonstrate that, similar to other $\mathrm{AD}$ transgenic models, 5XFAD mice develop memory deficits with age.

\section{Discussion}

5XFAD mice: rapid amyloid pathology models

To substantially accelerate amyloid deposition in vivo, we made transgenic mouse lines that co-overexpress APP with three FAD 
A

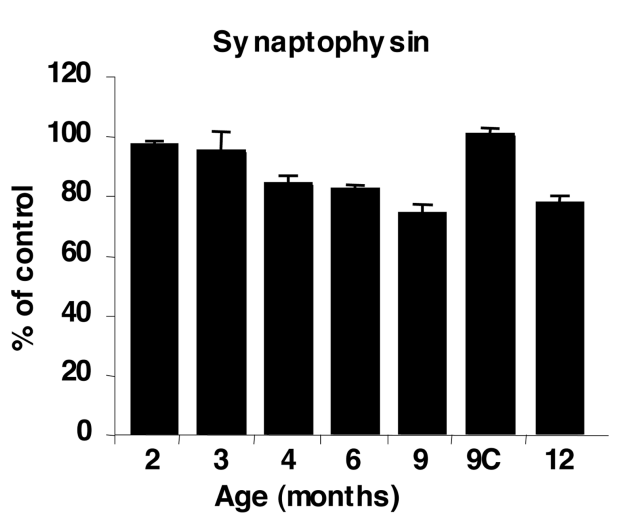

B

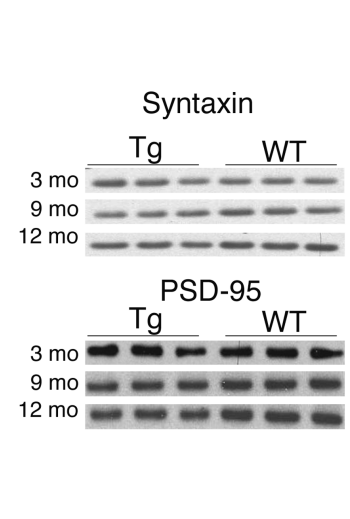

C

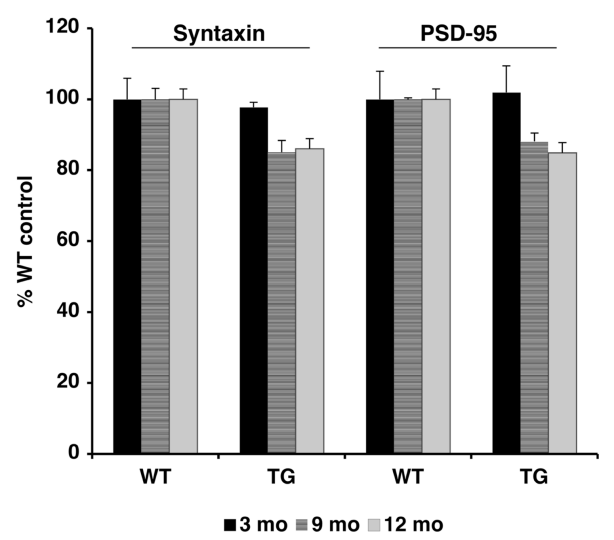

Figure 6. Reduced synaptophysin, syntaxin, and PSD-95 levels in Tg6799: synaptic degeneration. $\boldsymbol{A}$, Whole-brain homogenates from 2-to 12 -month-0ld Tg6799 and 9-month-old nontransgenic control $(9 C)$ mice were analyzed for synaptophysin by ELISA. Synaptophysin levels are expressed as the percentage of 9-month-old control whole-brain synaptophysin levels ( 9 C is $100 \%)$. No significant gender differences were observed in Tg6799 synaptophysin levels at any given age (data not shown), so values from age-matched males and females were pooled (3 mice for each gender and age). Note the steady decline in synaptophysin levels starting at 4 months in Tg6799, eventually falling to $\sim 75 \%$ of control levels at 9 months. B, C, Immunoblot analysis of synaptic markers syntaxin and PSD-95 in cortex homogenates (15 mg) from $\operatorname{Tg} 6799$ (Tg) and nontransgenic (wild type, WT) mice (3, 9, and 12 months old). Equal loading was determined by ponceau red staining of the blots (data not shown). Immunoblot signals were captured using a Phosphorlmager (B), quantified, and expressed as percentage of age-matched control (C). Note that synaptic markers are significantly reduced by 9 months of age in $\mathrm{Tg} 6799$, indicating neurodegeneration. Error bars represent SEM.

mutations (K670N/M671L, I716V, and V717I) and PS1 with two FAD mutations (M146L and L286V) with the neuron-specific Thyl promoter. $5 \mathrm{XFAD}$ mice breed as single transgenics and produce massive levels of cerebral $\mathrm{A} \beta_{42}$, far exceeding those of $\mathrm{A} \beta_{40}$. Other $\mathrm{AD}$ transgenic mice have demonstrated that $\mathrm{A} \beta_{42}$ elevating FAD mutations in APP and PS1 additively increase $\mathrm{A} \beta_{42}$ production and accelerate amyloid deposition when in intermolecular combination (for review, see Spires and Hyman, 2005). Here, we show that FAD mutations when combined together both intramolecularly and intermolecularly act in an additive manner to markedly increase the generation of $\mathrm{A} \beta_{42}$ in vivo. As a consequence, 5XFAD mice develop AD-like amyloid pathology starting at a very young age ( 2 months, in line Tg6799). The 5XFAD pathologic phenotype consists of amyloid plaques, gliosis, neurodegeneration, and memory deficits. In addition, 5XFAD mice exhibit intraneuronal $\mathrm{A} \beta$ and obvious neuron loss, a fundamental characteristic of $\mathrm{AD}$ lacking in most $\mathrm{AD}$ transgenic models.

Recent studies have described intraneuronal $\mathrm{A} \beta$ accumulation in $\mathrm{AD}$ and $\mathrm{DS}$ brain and have reported that amyloid plaques appear to originate from neuron cell bodies or processes (for review, see Echeverria and Cuello, 2002; Tseng et al., 2004; Gouras et al., 2005). Some AD transgenic mice also display intraneuronal A $\beta$ (Takahashi et al., 2002; Oddo et al., 2003; Schmitz et al., 2004). Importantly, 5XFAD intraneuronal $A \beta$ aggregates into $\beta$-pleated sheet amyloid, as determined by thioflavin S staining, and it labels with anti-A $\beta_{42}$ end-specific antibody and can appear physically associated with amyloid plaques originating from neurons, similar to $\mathrm{AD}$ and $\mathrm{DS}$.

We did not expect 5XFAD mice to develop neurofibrillary tangles, because tangle pathology has not been reported in APP single- or APP/PS1 double-transgenic mice. However, unlike other APP transgenic mice, 5XFAD did not display abnormally phosphorylated tau epitopes (Sturchler-Pierrat et al., 1997). The reason for the lack of phospho-tau immunoreactivity in 5XFAD brain is unclear, and additional analyses of pathologic tau epitopes in 5XFAD are required. Transgenic mice expressing human tau with the P301L frontotemporal dementia mutation develop neurofibrillary tangles when coexpressing an FAD mutant APP transgene (Lewis et al., 2001; Oddo et al., 2003) or after injection with $\mathrm{A} \beta_{42}$ (Gotz et al., 2001), indicating that $\mathrm{A} \beta_{42}$ promotes tangle formation. Crosses of 5 XFAD with P301L tau mice will be valuable for investigating the effects of very high $\mathrm{A} \beta_{42}$ levels on the development of neurofibrillary tangles.

Although 5XFAD mice recapitulate major characteristics of AD-relevant amyloid pathology, caveats must be considered when interpreting the 5XFAD phenotype and its relationship to human AD. First, no cases of AD are caused by multiple FAD mutations, and unanticipated effects on APP processing could potentially occur as a consequence of the mutation combination in $5 \mathrm{XFAD}$ mice. Second, the $\mathrm{A} \beta_{42} / \mathrm{A} \beta_{40}$ ratio appears to be higher in $5 X F A D$ than in human $\mathrm{AD}$, thus raising the possibility that a greater level of $A \beta_{42}$ toxicity exists in $5 X F A D$ than is typical in $\mathrm{AD}$ brain. In general, all $\mathrm{AD}$ transgenic mouse models face similar criticisms because of the overexpression of one or more FAD mutations, yet they have provided invaluable insight into AD pathogenesis and therapeutic strategies. The fact that 5XFAD amyloid pathology is similar to, but more rapid than, that found in $\mathrm{AD}$ and other $\mathrm{AD}$ transgenics indicates that $5 \mathrm{XFAD}$ mice are potentially relevant and useful models of $\mathrm{AD}$-like amyloidosis, although, like all animal models, caution should be exercised when relating the $5 \mathrm{XFAD}$ phenotype to human $\mathrm{AD}$.

\section{Intraneuronal $\mathrm{A} \boldsymbol{\beta}$, neurodegeneration, and amyloid plaque formation}

In the highest expressing 5XFAD line, Tg6799, intraneuronal A $\beta$ is evident at 1.5 months of age, just before the first appearance of amyloid deposits at 2 months. In DS and APP transgenics, intraneuronal $A \beta$ accumulation has also been observed before the formation of plaques (Gyure et al., 2001; Busciglio et al., 2002; Oddo et al., 2003; Cataldo et al., 2004; Schmitz et al., 2004), suggesting the possibility that build-up of $\mathrm{A} \beta$ within neurons may play a role in plaque formation and neurodegeneration. Importantly, intraneuronal $\mathrm{A} \beta_{42}$ was observed in the brains of young ( $\sim 3-4$ years old) DS patients (Gouras et al., 2000; Mori et al., 2002), years before plaques develop. In Tg6799, intraneuronal $\mathrm{A} \beta$ accumulation is prominent within large pyramidal neurons of layer 5 cortex and subiculum, possibly a result of the Thyl transgene promoter expression pattern (Feng et al., 2000). Much of 


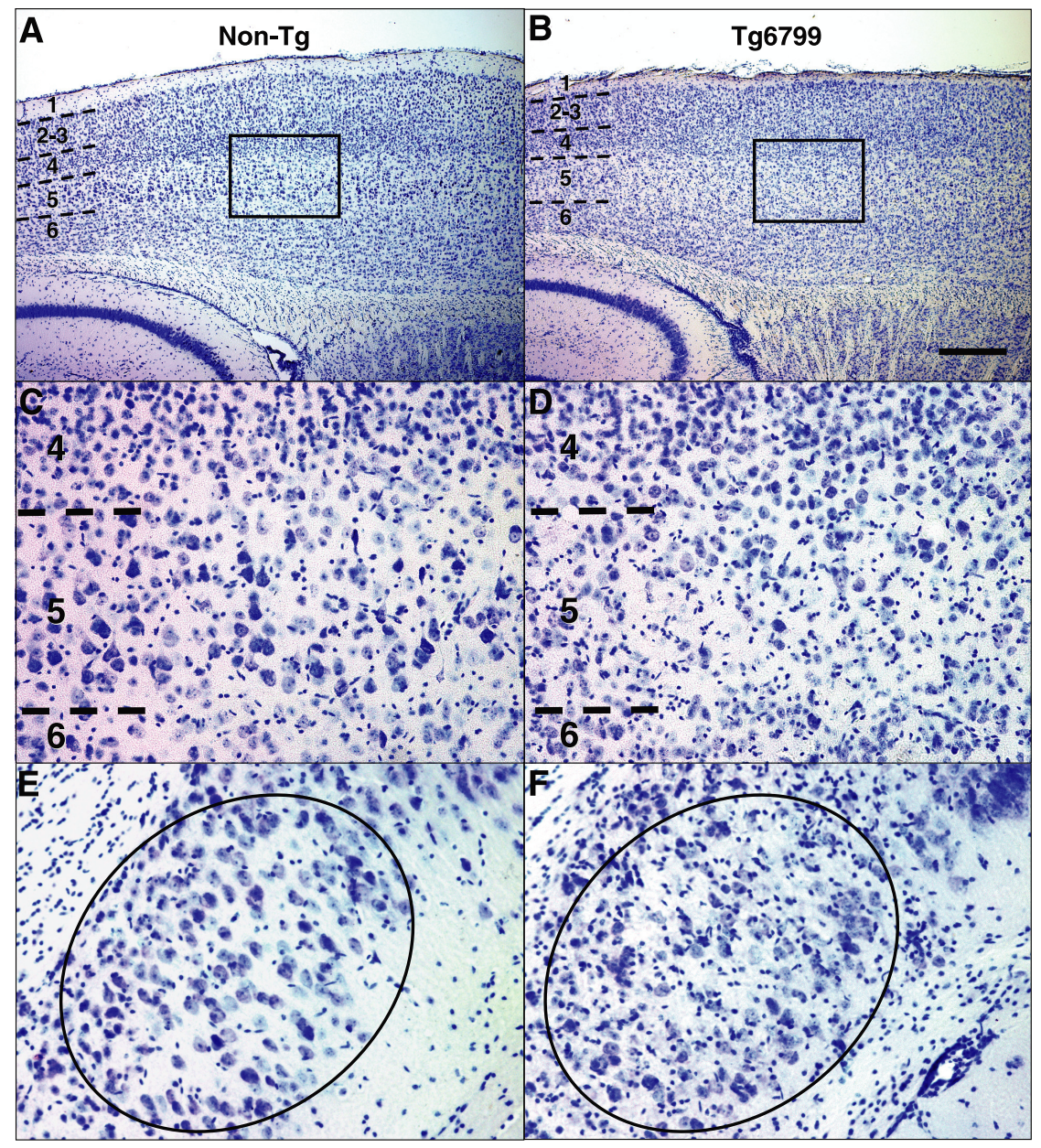

Figure 7. Neuron loss in cortical layer 5 and subiculum of Tg6799. Parasagittal sections of representative 9-month-old nontransgenic (Non-Tg) control $(\boldsymbol{A}, \boldsymbol{C}, \boldsymbol{E})$ and $\operatorname{Tg} 6799(\boldsymbol{B}, \boldsymbol{D}, \boldsymbol{F})$ brains were stained with cresyl violet and micrographed to image layer 5 cortex $(\boldsymbol{A}-\boldsymbol{D})$ and subiculum $(\boldsymbol{E}, \boldsymbol{F})$. Numbers indicate cortical layers, and dashed lines identify boundaries between layers. Boxes in $\boldsymbol{A}$ and $\boldsymbol{B}$ delineate areas of cortex shown at higher magnification in $\boldsymbol{C}$ and $\boldsymbol{D}$, respectively, to clearly visualize layer 5 . $\boldsymbol{B}, \boldsymbol{D}$, Note that large pyramidal neurons in cortical layer 5 are visibly reduced in number in $\operatorname{Tg} 6799$. Moreover, layer 1 of $\operatorname{Tg} 6799$ cortex $(\boldsymbol{B})$ is thinner than that of nontransgenics $(\boldsymbol{A})$. Neuron loss is also visible in $\mathrm{Tg} 6799$ subiculum (oval, $\boldsymbol{F}$ ) compared with that of nontransgenics (oval, $\boldsymbol{E}$ ). In addition, note the large number of glia in Tg6799 subiculum (small darkly staining cells, $\boldsymbol{F}$ ). Neurons are distinguishable from glial cells because of the larger size of neuronal cell body and the usual appearance of a prominent nuclear nucleolus. Layer 5 and subiculum exhibited the highest levels of both intraneuronal $A \beta$ accumulation and amyloid deposition in Tg6799 (for $A \beta_{42}$ immunostaining of a section adjacent to that in $\boldsymbol{B}$, see Fig. 4D) Scale bar (in $\boldsymbol{B}$ ): $\boldsymbol{A}, \boldsymbol{B}, 1 \mathrm{~mm} ; \boldsymbol{C}-\boldsymbol{F}, 100 \mu \mathrm{m}$. and the effects of intraneuronal $A \beta$ aggregates on intracellular trafficking in 5XFAD mice.

$\beta$-Sheet-structured $\mathrm{A} \beta$ may be neurotoxic (Urbanc et al., 2002), and several observations suggest that the thioflavin $\mathrm{S}$-positive intraneuronal $\mathrm{A} \beta$ aggregates in 5XFAD mice may cause neurodegeneration: (1) presynaptic markers synaptophysin and syntaxin are reduced; (2) postsynaptic marker PSD-95 is reduced; (3) intraneuronal $\mathrm{A} \beta$-containing neurons frequently exhibit weak NeuN immunostaining and abnormal morphologies and sometimes are physically associated with amyloid deposits; (4) large pyramidal neurons of layer 5 cortex and subiculum are markedly lost, exhibit prominent intraneuronal $\mathrm{A} \beta$ staining, and are located in regions of high plaque burden; and (5) p25 levels are increased. Importantly, p25 elevation may be an early event in 5XFAD brain, trending upward by 3 months of age and temporally coinciding with the accumulation of intraneuronal $\mathrm{A} \beta$. By 9 months of age, the p 25 increase in 5XFAD brain is significant and correlates with marked synaptic degeneration and neuron loss. Calpain cleavage generates p25, which in turn activates cyclin-dependent kinase $5(\mathrm{cdk} 5)$, a potential player in the connection between $\mathrm{A} \beta$ toxicity, neurodegeneration, and neurofibrillary tangle formation in $\mathrm{AD}$ (for review, see Cruz and Tsai, 2004). Although our work does not unequivocally prove that intraneuronal $\mathrm{A} \beta$ aggregates cause neuronal degeneration, it provides initial insights into a potential molecular mechanism that may link intraneuronal $A \beta$ and neurodegeneration. Taken as a whole, our results suggest that intraneuronal $\mathrm{A} \beta_{42}$ aggregates may play a role in neurodegeneration, neuron loss, and the formation of amyloid plaques.

the intraneuronal $\mathrm{A} \beta$ is within soma, although intracellular $\mathrm{A} \beta$ is also observed in neuronal processes. Immunoreactivity with anti$\mathrm{A} \beta_{42}$ end-specific antibodies demonstrates that intraneuronal staining identifies bona fide $\mathrm{A} \beta_{42}$ rather than APP or APP CTFs.

Intraneuronal $\mathrm{A} \beta$ labeling in $5 \mathrm{XFAD}$ brain is primarily punctate, suggesting vesicular compartmentalization. We have not yet determined the subcellular compartments in which intraneuronal $\mathrm{A} \beta$ inclusions occur. Based on extensive intracellular localization studies of APP and the secretases, we speculate that aggregated intraneuronal $\mathrm{A} \beta$ likely occurs within acidic compartments such as endosomes. Interestingly, Takahashi et al. (2002) have identified multi-vesicular bodies, or late endosomes, as compartments in which intracellular A $\beta$ accumulates in AD and APP transgenic brains. We also observe large intraneuronal $\mathrm{A} \beta$ accumulations occurring near the axon hillock. This latter observation, together with anti-A $\beta$ antibody and thioflavin $\mathrm{S}$ staining in neurites, suggests that aggregated intraneuronal $A \beta$ may interfere with axonal and/or dendritic transport. Future studies will determine the subcellular compartments in which $\mathrm{A} \beta$ accumulates
Robust neuronal loss has not been observed in most APP transgenic mouse models. However, a recent APP/PS1 line coexpressing APP K670N/M671L plus V717I and PS1 M233T plus L235P (APP $\left.{ }^{\mathrm{SL}} \mathrm{PS} 1 \mathrm{KI}\right)$ exhibits significant neuron death in CA1/2 of the hippocampus (Casas et al., 2004; Schmitz et al., 2004). Like $5 \mathrm{XFAD}$ mice, the neuron loss in $\mathrm{APP}{ }^{\mathrm{SL}} \mathrm{PS} 1 \mathrm{KI}$ mice is preceded by intraneuronal $\mathrm{A} \beta$, although intraneuronal $\mathrm{A} \beta$ does not appear to cause amyloid plaque formation in this model. Other APP transgenics also display intraneuronal $\mathrm{A} \beta$ but do not have significant neuron death (Takahashi et al., 2002; Oddo et al., 2003). Why intraneuronal $\mathrm{A} \beta$ does not always correlate with neuron loss and plaque formation in APP transgenics is unclear, but the reason may be related to the different combinations of FAD mutants, expression levels, and promoters used in each line. Regardless, neuron loss is correlated with previous appearance of thioflavin $\mathrm{S}$-positive intraneuronal $\mathrm{A} \beta$ aggregates in both 5XFAD and $\mathrm{APP}^{\mathrm{SL}} \mathrm{PS} 1 \mathrm{KI}$ mice.

Lee et al. (2005) have shown that $\beta$-site APP-cleaving enzyme 1 (BACE1) overexpression in $\operatorname{Tg} 2576$ mice causes $A \beta$ production 
A

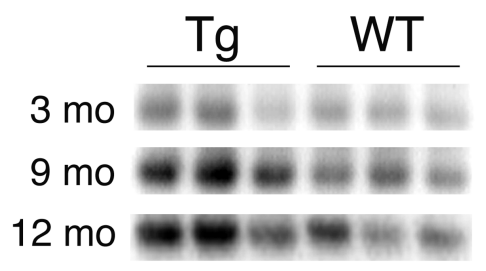

B

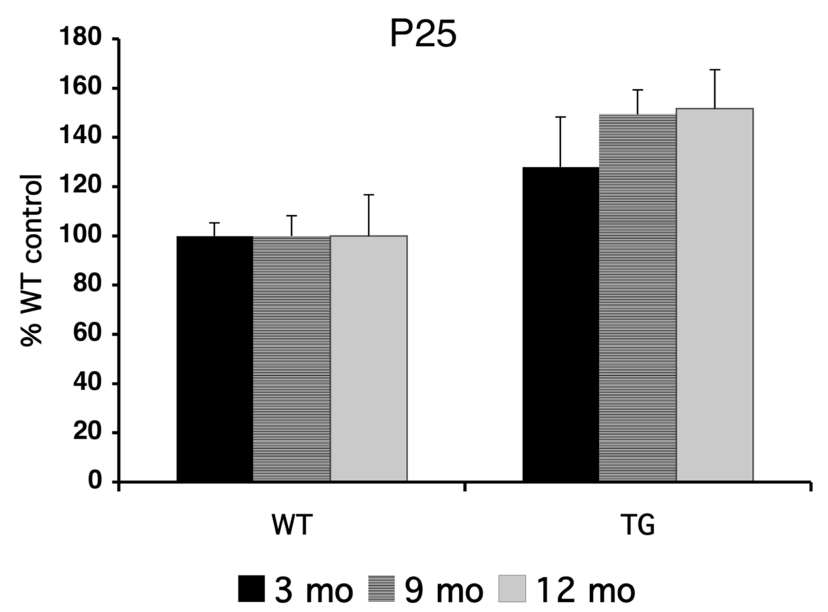

Figure 8. p25 levels are increased in Tg6799 mice. Immunoblot analysis of the cdk5 activating subunit p25 in cortex homogenates $(15 \mathrm{mg})$ from $\mathrm{Tg} 6799(\mathrm{Tg})$ and nontransgenic (wildtype, WT) mice (3, 9, and 12 months old). Equal loading was determined by ponceau red staining of the blots (data not shown). Immunoblot signals were captured using a Phosphorlmager $(\boldsymbol{A})$, quantified, and expressed as percentage of age-matched control $(\boldsymbol{B})$. Note that p25 levels are significantly elevated by 9 months of age in Tg6799 but that a trend toward higher values can be seen at 3 months. Error bars represent SEM.

to shift from the axonal compartment to the somatodendritic compartment in which it is efficiently degraded, thus reducing steady-state $\mathrm{A} \beta$ levels and plaque deposition. In contrast, we observe soma-derived deposits in 5XFAD brain, which may be a result of high $\mathrm{A} \beta_{42}$ generation in $5 \mathrm{XFAD}$ relative to Tg2576. It is well established that $\mathrm{A} \beta_{42}$ becomes aggregated more readily than $\mathrm{A} \beta_{40}$, especially under acidic conditions (as occurs in endosomes). We speculate that high $\mathrm{A} \beta_{42}$ concentrations within acidic intracellular compartments could lead to $\mathrm{A} \beta_{42}$ aggregation, which in turn may impair $A \beta$-degrading mechanisms or inhibit $\mathrm{A} \beta$ secretion in the soma. As a result, $\mathrm{A} \beta_{42}$ aggregates may accumulate, damage membranes, cause neuron lysis, and form plaque seeds. It is conceivable that such conditions may occur in $\mathrm{AD}$ with $\mathrm{A} \beta_{42}$-elevating FAD mutations. Although it is unclear whether $\mathrm{A} \beta_{42}$ levels within sporadic $\mathrm{AD}$ neurons become high enough to allow intraneuronal $\mathrm{A} \beta_{42}$ aggregation and plaque formation, the observation that amyloid plaques appear to originate from degenerated neuron cell bodies in AD (Gouras et al., 2000; D'Andrea et al., 2001) is consistent with this hypothesis.

Recently, transgenic mice expressing a BRI protein $-\mathrm{A} \beta_{42}$ fusion construct that generates only $A \beta_{42}$ in the brain have firmly established that $\mathrm{A} \beta_{42}$ is essential for parenchymal and vascular amyloid deposition (McGowan et al., 2005). In contrast to 5XFAD mice, little evidence of intraneuronal $\mathrm{A} \beta$ was found in BRI-A $\beta_{42}$ transgenic brain. The absence of intraneuronal $\mathrm{A} \beta$ accumulation in BRI-A $\beta_{42}$ mice may be related to the different processing and trafficking pathways that generate $\mathrm{A} \beta$ from BRI$\mathrm{A} \beta_{42}$ fusion protein compared with full-length APP: BRI-A $\beta_{42}$ is processed by furin in the trans-Golgi (potentially allowing efficient $\mathrm{A} \beta_{42}$ secretion), whereas APP is cleaved by secretases in endosomes (possibly favoring $\mathrm{A} \beta_{42}$ aggregation). Thus, intraneuronal $\mathrm{A} \beta_{42}$ accumulation may partly depend on the intracellular compartment in which $\mathrm{A} \beta_{42}$ is generated.

The apolipoprotein E4 (ApoE4) is a well established risk factor for $\mathrm{AD}$ that has been shown to enhance $\mathrm{A} \beta$ deposition in vivo (for review, see Bales et al., 2002), although the mechanisms involved are poorly understood and it is unknown whether ApoE isoform affects the aggregation of intraneuronal $\mathrm{A} \beta$. ApoE is secreted by astrocytes and then is endocytosed by neurons in which it may encounter $A \beta$ in endosomes. It is conceivable that, under conditions in which intraneuronal $\mathrm{A} \beta_{42}$ concentrations in endosomes are high, interaction between $\mathrm{A} \beta_{42}$ and ApoE4 may facilitate intracellular aggregation. Although the amount of extracellular ApoE in the brain is likely to far exceed that of intracellular ApoE, it is possible that local concentrations of endocytosed ApoE within intraneuronal compartments may reach high levels. Thus, ApoE isoform may affect both intracellular and extracellular $\mathrm{A} \beta$ aggregation. Crossing 5XFAD with different ApoE isoform transgenic mice will allow investigation of this question.

Plaques in 5XFAD mice are smaller, more numerous, and more densely packed than those in $\operatorname{Tg} 2576$. We propose that the very high $\mathrm{A} \beta_{42} / \mathrm{A} \beta_{40}$ ratio in $5 \mathrm{XFAD}$ may promote plaque nidus formation. Our results are consistent with those of Hyman et al. (1995) showing that higher $\mathrm{A} \beta$ production with normal $\mathrm{A} \beta_{42} /$ $\mathrm{A} \beta_{40}$ ratio (e.g., DS) causes larger plaque size, whereas greater plaque initiation (e.g., $\mathrm{AD}$ with $\mathrm{ApoE} 4$ or $\mathrm{A} \beta_{42}$-elevation mutations) favors higher plaque number.

It should be stressed that multiple pathways of amyloid plaque formation are likely to exist, in addition to the one involving intraneuronal $\mathrm{A} \beta$ aggregates in soma. For example, we also observe thioflavin S-positive $\mathrm{A} \beta$ aggregates within neurites of 5XFAD brain (Fig. 5F). It is not yet known whether these structures are axons or dendrites. Plaques are frequently seen in somapoor regions of neuropil and white matter (e.g., stratum oriens and stratum radiatum of the hippocampus, molecular layer of the dentate gyrus, and fimbria) (Fig. $4 D$ ), consistent with the hypothesis that $A \beta$ accumulation within neurites may contribute to degeneration and deposit formation (Takahashi et al., 2002). In addition, plaques appear to form from $A \beta$ released at the neuron terminal (Lazarov et al., 2002; Sheng et al., 2002), considered to be a major site of $A \beta$ generation and secretion. Our results do not exclude the possibility that a portion of plaques are derived from $\mathrm{A} \beta$ secreted at the terminal, and it is probable that both intraneuronal $\mathrm{A} \beta$ aggregates and extracellular $\mathrm{A} \beta$ may contribute to deposit formation in 5XFAD brain. As noted above, high $\mathrm{A} \beta_{42}$ production in 5XFAD neurons may enhance intracellular $A \beta$ accumulation relative to $A \beta$ secretion. Interestingly, a recent study has indicated an inverse dynamic relationship between intracellular and extracellular pools of $\mathrm{A} \beta$ that appears to influence deposit formation in 3XTg-AD mouse brain (Oddo et al., 2006). Thus, pathways leading to amyloid plaque formation are likely to be diverse and complex, possibly involving several distinct processes that occur in parallel during $\mathrm{AD}$.

\section{Memory impairment and intraneuronal $\mathrm{A} \beta$}

In the 3XTg-AD mouse model (Oddo et al., 2003), long-term retention memory deficits in the Morris water maze correlate with intraneuronal $\mathrm{A} \beta$ at 4 months, an age when mice do not have amyloid deposits (Billings et al., 2005). In contrast, 5XFAD mice do not have a Y-maze deficit at 2 months of age, although intraneuronal $\mathrm{A} \beta$ starts accumulating at 1.5 months. Unlike the water maze, the Y-maze task is not capable of assaying long-term memory retention, which may be responsible for the different 


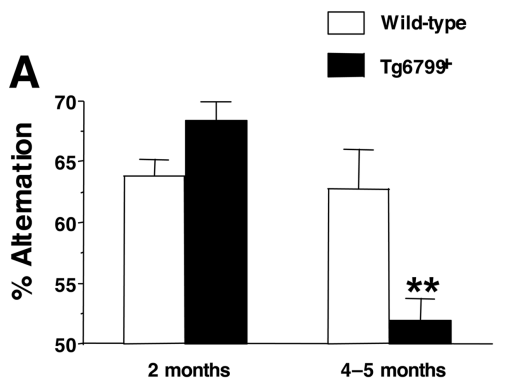

Figure 9. Memory deficits in Tg6799 mice with age. A, Spatial working memory of Tg6799 and nontransgenic littermate (Wild-type) mice was assessed by spontaneous alternation in the Y-maze $(n=12-20)$. Tg6799 mice showed normal alternation performance in the $Y$-maze at 2 months of age, but they performed poorly at $4-5$ months of age (only slightly $>50 \%$ chance levels) compared with nontransgenic littermate mice $\left(F_{(3,62)}=13.96 ; p<0.01\right)$. $\boldsymbol{B}$. The total number of arm entries was not different between Tg6799 and nontransgenic (Wild-type) control mice, indicating similar levels of motor and exploratory activity in the Y-maze $(n=12-21)$. Each column represents the mean \pm SEM. ${ }^{* *} p<0.01$ versus nontransgenic compared by ANOVA and post hoc Fisher's PLSD test.

behavioral results of the two models. Testing 2- to 4-month-old 5XFAD mice in the Morris water maze may reveal memory retention impairments that correlate with intraneuronal $\mathrm{A} \beta$. Conversely, we note that the $5 \mathrm{XFAD}$ Y-maze deficit appears at 4-5 months of age and correlates with the initial decline in whole-brain synaptophysin levels, raising the possibility that 5XFAD Y-maze memory dysfunction may be related to neurodegeneration.

In a previous study using Tg2576 mice, we showed that ablation of $\mathrm{A} \beta$ by targeted $\mathrm{BACE} 1$ gene deletion rescued the $\mathrm{Y}$-maze deficit of young pre-plaque Tg2576, suggesting that soluble A $\beta$ assemblies or oligomers, but not amyloid plaques, may be responsible for poor memory performance of Tg2576 (Ohno et al., 2004). However, we did not explore whether intraneuronal $\mathrm{A} \beta$ may have been involved in Tg2576 memory dysfunction. Multiple forms of $\mathrm{A} \beta$ are present in 4- to 5-month-old 5XFAD mice, including amyloid plaques, intraneuronal $\mathrm{A} \beta$ aggregates, and $\mathrm{A} \beta$ oligomers (Ohno et al., 2006). Therefore, the exact form(s) of $A \beta$ responsible for the poor performance of $5 \mathrm{XFAD}$ in the Y-maze is currently unknown and requires additional analysis. Finally, we note that, in addition to the Y-maze, 5XFAD mice also exhibit memory impairments in trace and contextual fear conditioning tests and the Morris water maze at 4-6 months of age (younger mice were not tested) (Ohno et al., 2006). Thus, in a variety of behavioral paradigms, 5XFAD mice display hippocampus-dependent memory deficits similar to those of other AD transgenic models.

In conclusion, 5XFAD mice are very rapid-onset amyloid plaque models that recapitulate major pathologic and behavioral characteristics of $\mathrm{AD}$. Importantly, $5 \mathrm{XFAD}$ mice provide evidence that intraneuronal $\mathrm{A} \beta$ aggregates may play a role in neurodegeneration, neuron loss, and amyloid plaque formation, suggesting that reduction of intraneuronal $\mathrm{A} \beta$ could be of potential therapeutic benefit for AD.

\section{References}

Akiyama H, Barger S, Barnum S, Bradt B, Bauer J, Cole GM, Cooper NR, Eikelenboom P, Emmerling M, Fiebich BL, Finch CE, Frautschy S, Griffin WS, Hampel H, Hull M, Landreth G, Lue L, Mrak R, Mackenzie IR, McGeer PL, et al. (2000) Inflammation and Alzheimer's disease. Neurobiol Aging 21:383-421.

Ashe KH (2001) Learning and memory in transgenic mice modeling Alzheimer's disease. Learn Mem 8:301-308.

Bales KR, Dodart JC, DeMattos RB, Holtzman DM, Paul SM (2002) Apolipoprotein E, amyloid, and Alzheimer disease. Mol Interv 2:363-375.

Biernat J, Mandelkow E-M, Schroter C, Lichtenberg-Kraag B, Steiner B, Berling B, Meyer H, Mercken M, Vandermeeren M, Goedert M, et al. (1992) The switch of tau protein to an Alzheimer-like state includes the phos- precursor proteins. Neuron 19:939-945.
Busciglio J, Pelsman A, Wong C, Pigino G, Yuan M, Mori H, Yankner BA (2002) Altered metabolism of the amyloid beta precursor protein is associated with mitochondrial dysfunction in Down's syndrome. Neuron 33:677-688.

Casas C, Sergeant N, Itier JM, Blanchard V, Wirths O, van der Kolk N, Vingtdeux V, van de Steeg E, Ret G, Canton T, Drobecq H, Clark A, Bonici B, Delacourte A, Benavides J, Schmitz C, Tremp G, Bayer TA, Benoit P, Pradier L (2004) Massive CA1/2 neuronal loss with intraneuronal and $\mathrm{N}$-terminal truncated Abeta 42 accumulation in a novel Alzheimer transgenic model. Am J Pathol 165:1289-1300.

Cataldo AM, Petanceska S, Terio NB, Peterhoff CM, Durham R, Mercken M, Mehta PD, Buxbaum J, Haroutunian V, Nixon RA (2004) Abeta localization in abnormal endosomes: association with earliest Abeta elevations in AD and Down syndrome. Neurobiol Aging 25:1263-1272.

Citron M, Westaway D, Xia W, Carlson G, Diehl T, Levesque G, JohnsonWood K, Lee M, Seubert P, Davis A, Kholodenko D, Motter R, Sherrington R, Perry B, Yao H, Strome R, Lieberburg I, Rommens J, Kim S, Schenk D, Fraser P, St George Hyslop P, Selkoe D (1997) Mutant presenilins of Alzheimer's disease increase production of 42-residue amyloid $\beta$-protein in both transfected cells and transgenic mice. Nat Med 3:67-72.

Citron M, Eckman CB, Diehl TS, Corcoran C, Ostaszewski BL, Xia W, Levesque G, St. George Hyslop P, S.G. Y, Selkoe DJ (1998) Additive effects of PS1 and APP mutations on secretion of the 42-residue amyloid beta-protein. Neurobiol Dis 5:107-116.

Craft JM, Watterson DM, Frautschy SA, Van Eldik LJ (2004) Aminopyridazines inhibit beta-amyloid-induced glial activation and neuronal damage in vivo. Neurobiol Aging 25:1283-1292.

Cruz JC, Tsai LH (2004) Cdk5 deregulation in the pathogenesis of Alzheimer's disease. Trends Mol Med 10:452-458.

D'Andrea MR, Nagele RG, Wang HY, Peterson PA, Lee DH (2001) Evidence that neurones accumulating amyloid can undergo lysis to form amyloid plaques in Alzheimer's disease. Histopathology 38:120-134.

Echeverria V, Cuello AC (2002) Intracellular A-beta amyloid, a sign for worse things to come? Mol Neurobiol 26:299-316.

Eckman CB, Mehta ND, Crook R, Perez-tur J, Prihar G, Pfeiffer E, GraffRadford N, Hinder P, Yager D, Zenk B, Refolo LM, Prada CM, Younkin SG, Hutton M, Hardy J (1997) A new pathogenic mutation in the APP gene (I716V) increases the relative proportion of A beta 42(43). Hum Mol Genet 6:2087-2089.

Esler WP, Wolfe MS (2001) A portrait of Alzheimer secretases-new features and familiar faces. Science 293:1449-1454.

Feng G, Mellor RH, Bernstein M, Keller-Peck C, Nguyen QT, Wallace M, Nerbonne JM, Lichtman JW, Sanes JR (2000) Imaging neuronal subsets in transgenic mice expressing multiple spectral variants of GFP. Neuron 28:41-51.

Games D, Adams D, Alessandrini R, Barbour R, Berthelette P, Blackwell C, Carr T, Clemens J, Donaldson T, Gillespie F, Guido T, Hagopian S, Johnson-Wood K, Khan K, Lee M, Leibowitz P, Lieberburg I, Little S, Masliah E, McConglue L, et al. (1995) Alzheimer-type neuroptahology 
in transgenic mice overexpressing V717F b-amyloid precursor protein. Nature 373:523-527.

Glenner GG, Wong CW (1984) Alzheimer's disease: initial report of the purification and characterization of a novel cerebrovascular amyloid protein. Biochem Biophys Res Commun 120:885-890.

Goate A, Chartier-Harlin MC, Mullan M, Brown J, Crawford F, Fidani L, Giuffra L, Haynes A, Irving N, James L, Mant R, Newton P, Rooke K, Roques P, Talbot C, Pericak-Vance M, Roses A, Williamson R, Rossor M, Owen M, Hardy J (1991) Segregation of a missense mutation in the amyloid precursor protein gene with familial Alzheimer's disease. Nature 349:704-706.

Gotz J, Chen F, van Dorpe J, Nitsch RM (2001) Formation of neurofibrillary tangles in P301l tau transgenic mice induced by A $\beta 42$ fibrils. Science 293:1491-1495.

Gouras GK, Tsai J, Naslund J, Vincent B, Edgar M, Checler F, Greenfield JP, Haroutunian V, Buxbaum JD, Xu H, Greengard P, Relkin NR (2000) Intraneuronal Abeta 42 accumulation in human brain. Am J Pathol 156:15-20.

Gouras GK, Almeida CG, Takahashi RH (2005) Intraneuronal Abeta accumulation and origin of plaques in Alzheimer's disease. Neurobiol Aging 26:1235-1244.

Gyure KA, Durham R, Stewart WF, Smialek JE, Troncoso JC (2001) Intraneuronal abeta-amyloid precedes development of amyloid plaques in Down syndrome. Arch Pathol Lab Med 125:489-492.

Hogan B, Beddington R, Costantini F, Lacy E (1994) Manipulating the mouse embryo: a laboratory manual, second Edition. Plainview, NY: Cold Spring Harbor Laboratory.

Holcomb L, Gordon MN, McGowan E, Yu X, Benkovic S, Jantzen P, Wright K, Saad I, Mueller R, Morgan D, Sanders S, Zehr C, O'Campo K, Hardy J, Prada CM, Eckman C, Younkin S, Hsiao K, Duff K (1998) Accelerated Alzheimer-type phenotype in transgenic mice carrying both mutant amyloid precursor protein and presenilin 1 transgenes. Nat Med 4:97-100.

Hsiao K, Chapman P, Nilsen S, Eckman C, Harigaya Y, Younkin S, Yang F, Cole G (1996) Correlative memory deficits, $A \beta$ elevation, and amyloid plaques in transgenic mice. Science 274:99-103.

Hutton M, Perez-Tur J, Hardy J (1998) Genetics of Alzheimer's disease. Essays Biochem 33:117-131.

Hyman BT, West HL, Rebeck GW, Buldyrev SV, Mantegna RN, Ukleja M, Havlin S, Stanley HE (1995) Quantitative analysis of senile plaques in Alzheimer's disease: observation of log-normal size distribution and molecular epidemiology of differences associated with apolipoprotein E genotype and trisomy 21 (Down syndrome). Proc Natl Acad Sci USA 92:3586-3590.

Jankowsky JL, Slunt HH, Ratovitski T, Jenkins NA, Copeland NG, Borchelt DR (2001) Co-expression of multiple transgenes in mouse CNS: a comparison of strategies. Biomol Eng 17:157-165.

Joachim CL, Games D, Morris J, Ward P, Frenkel D, Selkoe D (1991) Antibodies to non-beta regions of the beta-amyloid precursor protein detect a subset of senile plaques. Am J Pathol 138:373-384.

Lazarov O, Lee M, Peterson DA, Sisodia SS (2002) Evidence that synaptically released beta-amyloid accumulates as extracellular deposits in the hippocampus of transgenic mice. J Neurosci 22:9785-9793.

Lee EB, Zhang B, Liu K, Greenbaum EA, Doms RW, Trojanowski JQ, Lee VM (2005) BACE overexpression alters the subcellular processing of APP and inhibits Abeta deposition in vivo. J Cell Biol 168:291-302.

Lee VM-Y, Balin BJ, Otvos L, Trojanowski JQ (1991) A major subunit of paired helical filaments and derivatized forms of normal tau. Science 251:675-678.

Lewis J, Dickson DW, Lin WL, Chisholm L, Corral A, Jones G, Yen SH, Sahara N, Skipper L, Yager D, Eckman C, Hardy J, Hutton M, McGowan E (2001) Enhanced neurofibrillary degeneration in transgenic mice expressing mutant tau and APP. Science 293:1487-1491.

McGowan E, Pickford F, Kim J, Onstead L, Eriksen J, Yu C, Skipper L, Murphy MP, Beard J, Das P, Jansen K, Delucia M, Lin WL, Dolios G, Wang R, Eckman CB, Dickson DW, Hutton M, Hardy J, Golde T (2005) Abeta42 is essential for parenchymal and vascular amyloid deposition in mice. Neuron 47:191-199.

Moechars D, Lorent K, De Strooper B, Dewachter I, Van Leuven F (1996) Expression in brain of amyloid precursor protein mutated in the alphasecretase site causes disturbed behavior, neuronal degeneration and premature death in transgenic mice. EMBO J 15:1265-1274.
Moechars D, Dewachter I, Lorent K, Reverse D, Baekelandt V, Naidu A, Tesseur I, Spittaels K, Haute CV, Checler F, Godaux E, Cordell B, Van Leuven F (1999) Early phenotypic changes in transgenic mice that overexpress different mutants of amyloid precursor protein in brain. J Biol Chem 274:6483-6492.

Mori C, Spooner ET, Wisniewsk KE, Wisniewski TM, Yamaguch H, Saido TC, Tolan DR, Selkoe DJ, Lemere CA (2002) Intraneuronal Abeta42 accumulation in Down syndrome brain. Amyloid 9:88-102.

Mullan M, Crawford F, Houlden H, Axelman K, Lilius L, Winblad B, Lannfelt L (1992a) A pathogenic mutation for probable Alzheimer's disease in the APP gene at the N-terminus of beta-amyloid. Nat Genet 1:345-347.

Oddo S, Caccamo A, Shepherd JD, Murphy MP, Golde TE, Kayed R, Metherate R, Mattson MP, Akbari Y, LaFerla FM (2003) Triple-transgenic model of Alzheimer's disease with plaques and tangles: intracellular Abeta and synaptic dysfunction. Neuron 39:409-421.

Oddo S, Caccamo A, Smith IF, Green KN, Laferla FM (2006) A dynamic relationship between intracellular and extracellular pools of Abeta. Am J Pathol 168:184-194.

Ohno M, Sametsky EA, Younkin LH, Oakley H, Younkin SG, Citron M, Vassar R, Disterhoft JF (2004) BACE1 deficiency rescues memory deficits and cholinergic dysfunction in a mouse model of Alzheimer's disease. Neuron 41:27-33.

Ohno M, Chang L, Tseng W, Oakley H, Citron M, Klein WL, Vassar R, Disterhoft JF (2006) Temporal memory deficits in Alzheimer's mouse models: rescue by genetic deletion of BACE1. Eur J Neurosci 23:251-260.

Rogers JT, Leiter LM, McPhee J, Cahill CM, Zhan SS, Potter H, Nilsson LN (1999) Translation of the Alzheimer amyloid precursor protein mRNA is up-regulated by interleukin- 1 through $5^{\prime}$-untranslated region sequences. J Biol Chem 274:6421-6431.

Schlaf G, Salje C, Wetter A, Stuertz K, Felgenhauer K, Mader M (1998) Determination of synapsin I and synaptophysin in body fluids by two-site enzymelinked immunosorbent assays. J Immunol Methods 213:191-199.

Schmitz C, Rutten BP, Pielen A, Schafer S, Wirths O, Tremp G, Czech C, Blanchard V, Multhaup G, Rezaie P, Korr H, Steinbusch HW, Pradier L, Bayer TA (2004) Hippocampal neuron loss exceeds amyloid plaque load in a transgenic mouse model of Alzheimer's disease. Am J Pathol 164:1495-1502.

Selkoe DJ (2001) Alzheimer's disease: genes, proteins, and therapy. Physiol Rev 81:741-766.

Sheng JG, Price DL, Koliatsos VE (2002) Disruption of corticocortical connections ameliorates amyloid burden in terminal fields in a transgenic model of $\mathrm{A} \beta$ amyloidosis. J Neurosci 22:9794-9799.

Sisodia SS, Kim SH, Thinakaran G (1999) Function and dysfunction of the presenilins. Am J Hum Genet 65:7-12.

Spires TL, Hyman BT (2005) Transgenic models of Alzheimer's disease: learning from animals. NeuroRx 2:423-437.

Sturchler-Pierrat C, Abramowski D, Duke M, Wiederhold KH, Mistl C, Rothacher S, Ledermann B, Burki K, Frey P, Paganetti PA, Waridel C, Calhoun ME, Jucker M, Probst A, Staufenbiel M, Sommer B (1997) Two amyloid precursor protein transgenic mouse models with Alzheimer disease-like pathology. Proc Natl Acad Sci USA 94:13287-13292.

Takahashi RH, Milner TA, Li F, Nam EE, Edgar MA, Yamaguchi H, Beal MF, $\mathrm{Xu} \mathrm{H}$, Greengard P, Gouras GK (2002) Intraneuronal Alzheimer Abeta 42 accumulates in multivesicular bodies and is associated with synaptic pathology. Am J Pathol 161:1869-1879.

Takahashi RH, Almeida CG, Kearney PF, Yu F, Lin MT, Milner TA, Gouras GK (2004) Oligomerization of Alzheimer's $\beta$-amyloid within processes and synapses of cultured neurons and brain. J Neurosci 24:3592-3599.

Thinakaran G, Regard JB, Bouton CM, Harris CL, Price DL, Borchelt DR, Sisodia SS (1998) Stable association of presenilin derivatives and absence of presenilin interactions with APP. Neurobiol Dis 4:438-453.

Tseng BP, Kitazawa M, LaFerla FM (2004) Amyloid beta-peptide: the inside story. Curr Alzheimer Res 1:231-239.

Urbanc B, Cruz L, Le R, Sanders J, Ashe KH, Duff K, Stanley HE, Irizarry MC, Hyman BT (2002) Neurotoxic effects of thioflavin S-positive amyloid deposits in transgenic mice and Alzheimer's disease. Proc Natl Acad Sci USA 99:13990-13995.

Younkin SG (1998) The role of Abeta 42 in Alzheimer's disease. J Physiol (Paris) 92:289-292. 